Title Page

\title{
Inorganic Molybdenum Octahedral Nanosized Cluster Units, Versatile Functional Building Block for Nanoarchitectonics
}

\section{SI: Nanoarchitectonics}

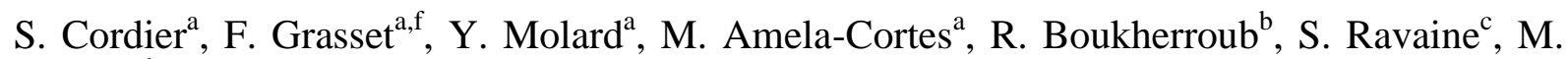
Mortier $^{\mathrm{d}}$, N. Ohashi ${ }^{\mathrm{e}}$, N. Saito ${ }^{\mathrm{e}}$ and H. Haneda ${ }^{\mathrm{e}}$

${ }^{a}$ Institut des Sciences Chimiques de Rennes, UMR 6226 UR1-CNRS, Université de Rennes 1, Campus de Beaulieu, 35042 Rennes Cedex, France

${ }^{\mathrm{b}}$ Institut de Recherche Interdisciplinaire (IRI, USR CNRS 3078), Université de Lille 1, Parc de la Haute Borne, 50 Avenue de Halley, BP 70478, 59658 Villeneuve d'Ascq, France

${ }^{\mathrm{c}}$ CNRS, Univ. Bordeaux, CRPP, UPR 8641, F-33600 Pessac, France

${ }^{\mathrm{d}}$ Institut de Recherche de Chimie Paris, CNRS - Chimie ParisTech, 11 rue Pierre et Marie

Curie, 75005 Paris, France

${ }^{\mathrm{e}}$ National Institute for Materials Science, 1-1 Namiki, Tsukuba, Ibaraki 305-0044, Japan

${ }^{\mathrm{f}}$ CNRS, UMI 3629, Laboratory for Innovative Key Materials and Structures-LINK, National Institute of Material Science, 1-1 Namiki, 305-0044, Tsukuba, Japan

Corresponding authors:

stephane.cordier@univ-rennes1.fr

yann.molard@univ-rennes1.fr

fabien.grasset@univ-rennes1.fr

\begin{abstract}
Recently, Nanoarchitectonics has been introduced as a new concept that refers to a technology system for arranging nanoscale structural units in a required architecture. Multifunctional properties are achieved by combination of several materials in well-defined architecture. In the frame of this concept, composite nanoarchitectures represent a new class of nanostructured entities that integrate various dissimilar nanoscale building blocks including clusters, particles, wires and films. The heterogeneous composite nanostructured materials are composed by definition of multi-(nano)components, each tailored to address different requirements. As one of the nanocomponents, nanometer sized metal clusters $(<2 \mathrm{~nm})$, which consist of less than a few dozens of metal atoms, could be defined as a link between atom and nanoparticle. In this paper, we will focus on our results on new nano-composites involving $\mathrm{Mo}_{6}$ atom nanosized cluster unitsnanosized cluster units for optical, nanobiotechnology, energy and environmental applications.
\end{abstract}

Keywords: Nanoarchitectonics; Metal Nanoclusters; Molybdenum; Near Infra-red; hybrids; liquid crystal; Microemulsion 


\section{Introduction}

Recently, Aono introduced the general term of nanoarchitectonics [1] as a new concept that refers to a technology system for arranging nanoscale structural units in a required architecture. One of the final goals is to prepare new functional materials based on selfassembly with nanoscale precision. This approach has been applied for the preparation of several layered materials like ultrathin or mesoporous films [2, 3]. Often, the realization of multifunctional systems with enhanced mechanical, physico-chemical and structural properties is achieved by combination of several materials in well-defined architecture. In the frame of the nanoarchitectonics concept, composite nanoarchitectures represent a new class of nanostructured entities that integrate various dissimilar nanoscale building blocks including nanosized cluster units, nanoparticles, nanowires and nanofilms. The search for strategies to rationally and scalably assemble complex functional nanostructures in hierarchical fashion has attracted significant research interests. A huge number of efforts have been made due to the request in-demand and their potential applications in advanced devices and systems toward energy, environmental and sensing sectors for instance [4]. The heterogeneous composite nanostructured materials are composed by definition of multi-(nano)components, each tailored to address different requirements. As one of the nanocomponents, nanometer sized metal clusters $(<2 \mathrm{~nm})$ also called "nanoclusters", which consist of less than a few dozens of metal atoms, could be defined as a link between atom and nanoparticle. They have attracted more and more attention due to their unique electronic structures and the subsequent unusual physical and chemical properties. Indeed, due to the confinement of the metal atom valence electrons on discrete energy levels within molecular dimensions, metal atom clusters exhibit unique electronic and optical properties such as molecule-like energy gaps [5], strong photoluminescence with large stoke shift [6] or high catalytic properties [7]. The term "metal atom clustere was introduced by F.A. Cotton in 1964 [8] to define a finite group of metal atoms (two or more) that are held together by metal-metal bonds, in addition to being bonded to other non-metals. Since then, clusters of various metals, such as Au (probably the most studied one), Ag, Pd, Pt, Cu, Mo, Re...have been prepared and studied [9-14]. During the past decades, various methods have been developed to synthesize metal clusters on a nanometer scale. Similar to the preparation of nanoparticles, metal atoms nanocluster can generally be prepared through "bottom-up" or "top-down" approaches. For a "bottom-up" route, most of the synthesis are carried out in solution phase and wet chemical reduction [9-14]. For the "top-down" approach, etching process or colloidal chemistry can be used from "bulk" materials synthesized for instance by solid state chemistry [9-14]. In this paper, we will focus 
on our results on new nano-composites involving $\mathrm{Mo}_{6}$ atom nanosized cluster units for optical, nanobiotechnology, energy and environmental applications.

\section{General description of Molybdenum Nanosized cluster units:}

The discovery in 1971 of the $\mathrm{A}_{\mathrm{y}} \mathrm{Mo}_{6} \mathrm{Q}_{8}(\mathrm{Q}=$ chalcogen, $\mathrm{A}=$ cation $)$ Chevrel phases in the Inorganic Molecular and Solid State Chemistry Laboratory of Rennes University (actually the team "Solid State Chemistry and Materials" from the Institut des Sciences Chimiques de Rennes) was the starting point for a new field of research in chemistry dealing with $\mathrm{M}_{6}(\mathrm{M}=$ $\mathrm{Nb}, \mathrm{Ta}, \mathrm{Mo}, \mathrm{W}$ and $\mathrm{Re}$ ) halide and chalcohalide clusters prepared via solid state routes at high temperature $\left(750^{\circ} \mathrm{C}-1200^{\circ} \mathrm{C}\right)$ [9]. Solid state compounds prepared via high temperature exhibit a tremendous range of physical properties. The number of electrons involved in these metal-metal bonds, the so-called valence electron concentration (VEC), influences the general properties of the aggregates. In particular, their delocalization on the whole cluster leads to a wide range of specific physical properties such as luminescence [15] and molecular magnetism [16-17] that are of interest for different applications in various areas. The metallic cluster is generally covalently bonded to face-capping or edge-bridged ligands $\left(\mathrm{L}^{\mathrm{i}}\right.$, where $\mathrm{i}$ stands for inner) to form $\mathrm{M}_{\mathrm{x}} \mathrm{L}_{\mathrm{y}}^{\mathrm{i}}$ and is stabilized by terminal ligands $\left(\mathrm{L}^{\mathrm{a}}\right.$, where a stands for apical), yielding a so-called cluster unit (Figure 1 and Figure 2).

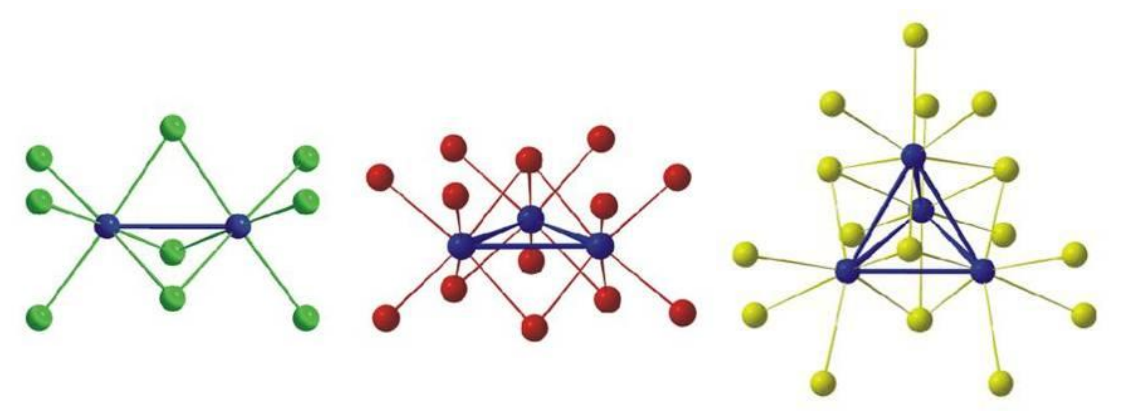

Fig. 1 Schematic illustrations of cluster units with linear, triangular and tetrahedral shapes (from left to right). The metallic cluster is represented in blue and non-metal ligands in green, red and yellow.

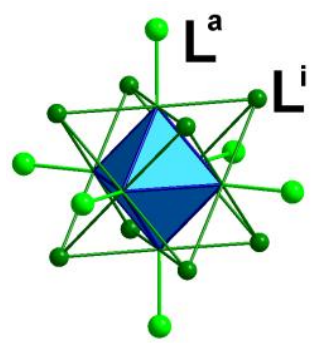

Fig. 2 Schematic representation of a $\left[\mathrm{Mo}_{6} \mathrm{~L}_{8}^{i} \mathrm{~L}_{6}^{\mathrm{a}}\right]^{2-}$ cluster unit. The $\mathrm{Mo}_{6}$ octahedral cluster is represented in blue. Apical ligands are in terminal positions $\left(\mathrm{L}^{\mathrm{a}}\right)$ and inner ligands are in face-capping positions $\left(\mathrm{L}^{\mathrm{i}}\right)$. 
These species, which can be discrete or condensed by either ligands or metals, constitute the basic building blocks of a wide range of inorganic, hybrid organic-inorganic, and supported materials and nanomaterials that can be prepared by either solid-state or solution chemistry [18-29]. Among the various families of metal clusters that encompass $3 d, 4 d$, and $5 d$ elements, inorganic molybdenum (Mo) cluster compounds present one of the most interesting and richest crystallo-chemistry in terms of the diversity and complexity of structural edifices [30-31]. Indeed, a very large number of nuclearities and geometries are encountered, from the simplest cluster made of triply bonded pairs of Mo atoms found in $\mathrm{LaR}_{4} \mathrm{Mo}_{36} \mathrm{O}_{52}(\mathrm{R}=\mathrm{Dy}, \mathrm{Er}$, $\mathrm{Yb}$, and Y) [32] to infinite chains of face-sharing octahedral clusters found in $\mathrm{Tl}_{2} \mathrm{Mo}_{6} \mathrm{Se}_{6}$ [3334]. Between these two compounds, a number of intermediate geometries and nuclearities are described, many of them exhibiting original properties. For example, trinuclear $\mathrm{Mo}_{3}$ clusters associated with dithiolene ligands have a great potential for the development of molecular conductors [35]. Very recently, Kibsgaard et al., built an appropriate active-site motif into a hydrogen-evolution catalyst with thiomolybdate $\left[\mathrm{Mo}_{3} \mathrm{~S}_{13}\right]^{2-}$ nanosized cluster units [36]. The tetrahedral geometry of the $\mathrm{Mo}_{4}$ cluster favors the formation of both clathrate frameworks with giant cells and spinel-related structures having a Mott insulator behavior [26]. The latter exhibit an electric-field-induced resistive switching that is actually studied for the design of a new generation of resistive random access memory [27]. The octahedral $\mathrm{Mo}_{6}$ cluster constitutes the most encountered aggregate among the families of molybdenum clusters. On the one hand, the three-dimensional condensation of $\mathrm{Mo}_{6}$ cluster units via ligands yields the superconducting Sergent-Chevrel phases [37], whereas a one-dimensional condensation yields the semiconducting $\mathrm{Mo}_{6} \mathrm{X}_{8} \mathrm{Y}_{2}$ compounds $(\mathrm{X}=$ halogen and $\mathrm{Y}=$ chalcogen) [38]. The latter, used as a precursor for the elaboration of $\mathrm{MoS}_{2}$ nanotubes and $\mathrm{MoO}_{3-\mathrm{x}}$ nanowires [39-40], can be considered as the first term of a new class of M-nanocluster based nanowire materials that was discovered 10 years ago [41-42]. Among others, they exhibit interesting optical and tribological properties [43-46], and are easily dispersed in organic solvents [47-49]. In the aforementioned solid-state materials, the cluster unit is used as the basic entity enabling the description of crystal and electronic structures. On the other hand, it turns out that their dissolution leads to discrete nanosized units in solution that can be used in the elaboration of molecular assemblies and nanomaterials [20]. Molecular compounds based on non-interacting [ $\left.\mathrm{Mo}_{6} \mathrm{X}_{14}\right]$ cluster units $(\mathrm{X}=$ halogen $)$ are characterized by insulating behavior combined with phosphorescent properties [50]. Indeed, they absorb from ultraviolet to visible and emit on a wide optical window that ranges from visible to near-IR with high quantum yields and lifetimes. The $\left[\left(\mathrm{M}_{6} \mathrm{~L}_{8}^{\mathrm{i}}\right) \mathrm{L}_{6}^{\mathrm{a}}\right]^{\mathrm{n}-}$ unit $(\mathrm{a}=$ apical, $\mathrm{i}=$ inner, Figure 3$)$ constitutes the basic building 
blocks in the octahedral cluster chemistry and is easily obtained via solid state synthesis with $4 \mathrm{~d}$ and $5 \mathrm{~d}$ transition elements associated with halogen or chalcogen [12]. The intrinsic properties of $\mathrm{Mo}_{6}$ cluster units -one or two electron reversible redox process, magnetism, photocatalysis and luminescence - depend on the nature of the metal and ligands. The solubilisation of $\mathrm{Mo}_{6}$ solid state compounds provides $\left[\left(\mathrm{Mo}_{6} \mathrm{~L}_{8}^{\mathrm{i}}\right) \mathrm{L}_{6}^{\mathrm{a}}\right]^{\mathrm{n}-}$ building blocks with individual properties (optical, electronic and redox) that can be further used for the design of functional nano-composite materials and surfaces.

\section{New nanostructured materials based on $\mathrm{Mo}_{6}$ Nanocluster for optical applications:}

Photoluminescent materials are playing a major role in applications related to photonics, optoelectronics or lighting [51-54]. Combining them with polymers allows the design of easyto-shape functional materials with enhanced applications versatility [55]. However, achieving homogeneous hybrid polymer materials with high inorganic content and without altering the processability of the organic matrix is still challenging. It requires a perfect balance between both components interaction to avoid any segregation that would end up with scattering problems and loss of transparency.

Few examples are found in the literature where hybrid polymers showing high and stable deep red luminescence properties are obtained by incorporation of octahedral clusters. The direct incorporation of inorganic species in the polymer has to be circumvented because strong interactions between the organic and inorganic entities constituting the hybrid materials are pre-requisite to obtain fully homogeneous and stable hybrid material $[56,57]$. The common methodology is based on the covalent grafting of up to six polymerizable units in apical positions of the inorganic cluster core [58-64].

To obtain a material containing $\mathrm{M}_{6}$ clusters suitable for optical directed applications, we incorporated the molecular cluster core namely $\left(\mathrm{Mo}_{6} \mathrm{Br}_{8}^{\mathrm{i}}\right)^{4+}$ in a poly-(methyl methacrylate) (PMMA) or polyvinylpyrrolidone (PVP) matrix and investigated the optical properties of the resulting hybrid material $[65,66]$. In the case of PMMA, it was chosen for its excellent optical properties (i.e., transparency from the near-UV to the near-IR regions, damage resistance in the range needed for optical applications), good mechanical properties, thermal stability, and easy shaping. The synthetic approach was based on our recent studies developed for the design of clustomesogen and on the solvent as monomer approach described by Golden et al. [58]. It consists of the preparation of a mother liquor containing a $\left(n-\mathrm{Bu}_{4} \mathrm{~N}\right)_{2}\left[\mathrm{Mo}_{6} \mathrm{Br}_{8} \mathrm{~F}_{6}\right]$ cluster precursor and methacrylic acid, aliquots of which are mixed with methylmethacrylate 
(MMA) and subsequently copolymerized by a radical process using AIBN (0.02 wt\%) as initiator. Several samples containing from 0 to $0.36 \mathrm{wt} \%$ of cluster were synthesized by this bulk polymerization process. Beside a plastizing effect at very low cluster content, increasing the cluster amount within the copolymer induces an expected increase of the $T_{g}$ and $M_{w}$, showing that the clusters are covalently linked to the polymer strands and act as cross-linking agents. Luminescence studies showed that the intrinsic properties of the parent cluster are well preserved in the PMMA matrix. These emissive properties were used successfully to sensitize trivalent $\mathrm{Er}^{3+}$ complex emission in the infrared region and within the polymer matrix. Indeed, introduction of $0.25 \mathrm{wt} \%$ of metallic cluster increases by factors from 4 to 6 the $\mathrm{Er}^{3+} \mathrm{IR}$ emission at $1.5 \mu \mathrm{m}$, thus validating the concept of trivalent rare-earth metal infrared luminescence sensitization by transition metal clusters. In order to drastically increase the cluster amount within the polymer, another strategy exploiting physical interactions between the organic and inorganic parts of the hybrid material was developed [67]. This approach takes advantage of the anionic character of the metallic cluster building blocks by exchanging the usual alkali counter-cations of $\mathrm{Cs}_{2} \mathrm{Mo}_{6} \mathrm{Br}_{14}$ with polymerizable organic ones. In our case, the 2- charge of the anionic cluster prevents high crosslinking and allows high cluster content without modifying significantly the physical properties of the polymer matrix. Thus, functional clusters were obtained by cationic metathesis from their cesium salt with a dimethyl ammonium cation bearing two long alkyl chains, one of which is terminated by a methacrylate function (scheme 1) [68,69]. Several copolymers containing up to $50 \mathrm{wt} \%$ of hybrid cluster were synthesized in bulk by radical polymerization.

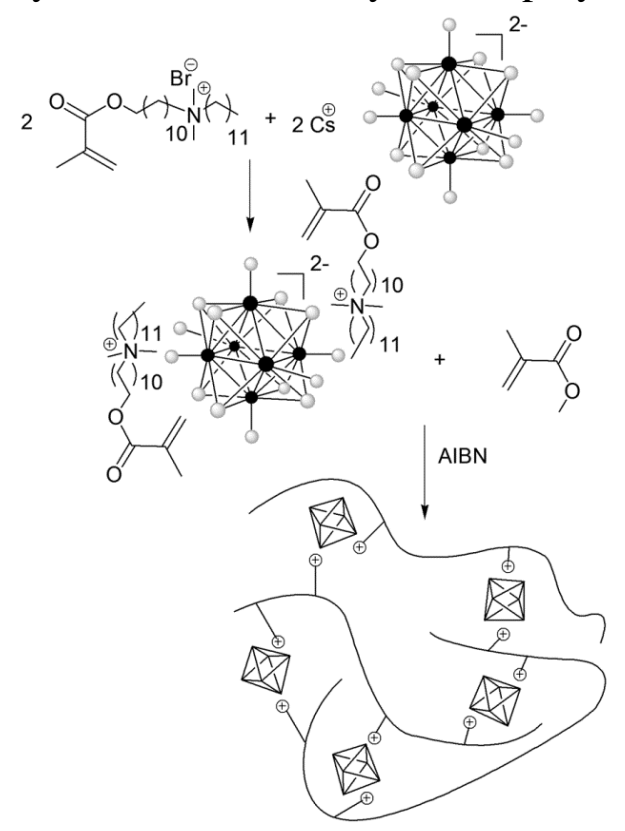

Scheme 1 Synthetic scheme of hybrid polymers. Black disks represent Mo atoms while grey ones are bromine atoms. Reprinted with permission from [67]. Reproduced by permission of The Royal Society of Chemistry. 


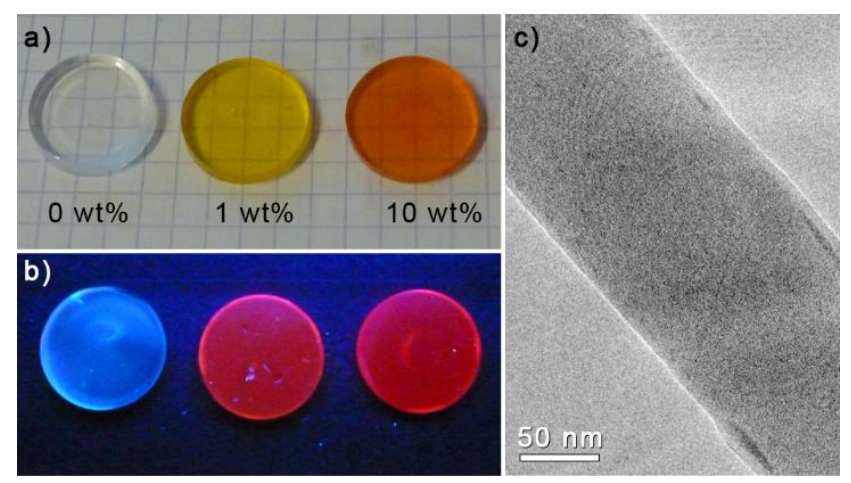

Fig. 3 Digital photographs of the $\mathrm{Mo}_{6}$-PMMA hybrid copolymer pellets under visible (a) and UV (b, $\lambda_{\text {exc }}=365$ $\mathrm{nm}$ ) light; c) T.E.M. picture of PM10. Reprinted with permission from [67]. Reproduced by permission of The Royal Society of Chemistry.

The influence of the cluster concentration on the copolymer thermal stability was studied by differential scanning calorimetry (DSC) and thermogravimetric analysis (TGA) by comparing the degradation temperatures of all samples under $\mathrm{N}_{2}$ atmosphere. The introduction of inorganic clusters does not modify significantly the thermal decomposition temperature or the glass transition temperature of the organic host even at high content, thanks to the di-anionic character of the $\mathrm{Mo}_{6}$ which affords weak crosslinking ability. By this method, we demonstrated that transition metal clusters with a low anionic charge can be introduced at very high loading in a polymer matrix, and, that this hybrid matrix remains homogeneous and highly stable even after several months of ageing. The deep red phosphorescence, characteristic of octahedral molybdenum clusters, occurs in the hybrid material on a large bandwidth extending from $600 \mathrm{~nm}$ to $850 \mathrm{~nm}$ at $293 \mathrm{~K}$ (Figure 3) and becomes even deeper red upon cooling.

The control of the nanostructuration in hybrid materials is a major challenge that requires the development of bottom-up approaches in their synthetical processes. Thus, liquid crystalline (LC) hybrid materials are actually in a stage of rapid development [70]. Indeed, LC materials are easy to process, are able to spontaneously self-assemble over large areas into highly ordered domains and show structural defects self-healing abilities [71]. It is however challenging to obtain liquid crystalline octahedral metallic cluster complexes because the clusters coordination behavior is poorly compatible with the structural requirements to achieve liquid-crystal phases (disk-like or rod-like geometry) [72, 73]. The strategy developed, by our group, to obtain mesomorphic hybrid clusters is based on the grafting of cyanobiphenyl $(\mathrm{CB})$ mesomorphic promoters through a flexible aliphatic spacer onto the bulky isotropic inorganic moiety by reaction, in our case, of benzoic acid derivatives with 
$\left(\mathrm{nBu}_{4} \mathrm{~N}\right)_{2}\left[\mathrm{Mo}_{6} \mathrm{Br}_{8} \mathrm{~F}_{6}\right]$. These carboxylic acid derivatives, namely $\mathrm{HL}^{3,4,5}, \mathrm{HL}^{3,4}$, and $\mathrm{HL}^{3,5}$, are based on a polysubstituted benzoic acid scaffold linked to CB moieties by a decyloxy alkyl chain (Figure 4). Single crystals suitable for X-ray diffraction analysis were obtained after reacting gallic acid with $\left(\mathrm{nBu}_{4} \mathrm{~N}\right)_{2}\left[\mathrm{Mo}_{6} \mathrm{Br}_{8} \mathrm{~F}_{6}\right]$ [74-76]. Their analysis showed that gallate were grafted in apical position of the cluster core by M-O single bonds. According to Saez et al. [77], hexasubsituted clusters could be seen as monodispersed polypedal supermolecular materials in which the metallic cluster plays the role of the central hard core scaffold in the dendritic architecture, while $\mathrm{CB}$ units are terminally attached via a spacer chain to this core. In such a case, the self-organization process depends on the density of mesogenic groups, their nature, and on how they are attached (terminally or laterally) to the central core.
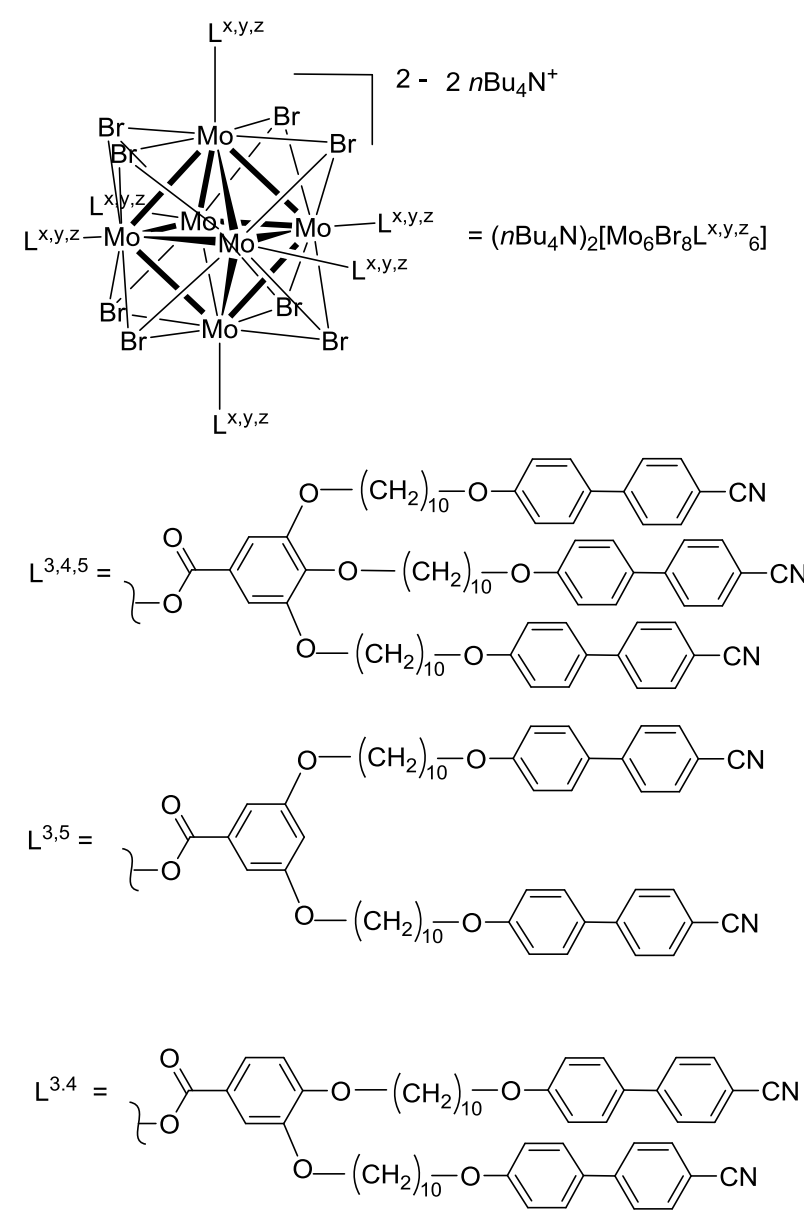

Fig. 4 Molecular structure representation of clustomesogens obtained by the covalent route.

Mesomorphic properties were studied by differential scanning calorimetry (DSC), polarized optical microscopy (POM) and temperature variable small angle $\mathrm{x}$-ray scattering (SAXS). All supermolecular compounds show enantiotropic liquid crystalline behavior on a wide temperature range (Table 1) and self-organize into lamellar configuration (Figure 5). 
The clearing points are observable around $100^{\circ} \mathrm{C}$, which makes this material suitable for processing of thin films by thermal annealing taking into consideration that the upper temperature limit for fabrication of devices on flexible plastic substrates is considered to be $200^{\circ} \mathrm{C}$ [78]. The formation of a nematic phase for $\left(n \mathrm{Bu}_{4} \mathrm{~N}\right)_{2}\left[\mathrm{Mo}_{6} \mathrm{Br}_{8} \mathrm{~L}^{3,5}{ }_{6}\right]$, the most fluid of the liquid crystal phases, between $94^{\circ} \mathrm{C}$ and $83^{\circ} \mathrm{C}$, allows the alignment of the molecules upon application of a magnetic field. Let us stress that this compound constitutes one of the rare example of ionic compound showing a nematic phase. To explain this behavior, we developed an innovative approach using a specific molecular modeling method usually used in the case of inert compounds. Calculations revealed that the presence of the nematic phase could be attributed to the $\left(n \mathrm{Bu}_{4} \mathrm{~N}\right)_{2}\left[\mathrm{Mo}_{6} \mathrm{Br}_{8} \mathrm{~L}^{3,5}{ }_{6}\right]$ ability to interact by interdigitation with its neighbors. The fluidity of the latter can be largely increased by mixing with commercially available LC mixture like E44. This miscibility, combined to the ease of synthesis of this class of compounds, make them good candidates for further integration into devices such as flexible displays or sensors.

Table 1. Phase behavior, transition temperatures and melting enthalpies of $\left(\mathrm{nBu}_{4} \mathrm{~N}\right)_{2}\left[\mathrm{Mo}_{6} \mathrm{Br}_{8} \mathrm{~L}^{\mathrm{x}, \mathrm{y}, \mathrm{z}}{ }_{6}\right]$ taken from

\begin{tabular}{|c|c|c|c|c|c|}
\hline Compound & Transition & $\mathrm{T}\left[{ }^{\circ} \mathrm{C}\right]$ & $\Delta C p^{[c]}$ & $\Delta \mathrm{H}^{[\mathrm{d}]}$ & $\Delta \mathrm{H} / \mathrm{nb}_{\mathrm{CB}}$ \\
\hline \multirow[t]{2}{*}{$\left(n \mathrm{Bu}_{4} \mathrm{~N}\right)_{2}\left[\mathrm{Mo}_{6} \mathrm{Br}_{8} \mathrm{~L}_{6}^{3,4,5}\right]$} & $\mathrm{I} \rightarrow \mathrm{Sm}$ & 103 & - & 32.94 & 1.83 \\
\hline & $\mathrm{Sm} \rightarrow \mathrm{G}$ & 23 & 4.29 & - & - \\
\hline \multirow[t]{3}{*}{$\left(n \mathrm{Bu}_{4} \mathrm{~N}\right)_{2}\left[\mathrm{Mo}_{6} \mathrm{Br}_{8} \mathrm{~L}^{3,5}\right]$} & $\mathrm{I} \rightarrow \mathrm{N}$ & $94^{[\mathrm{a}]}$ & - & $13.15^{[b]}$ & 1.10 \\
\hline & $\mathrm{N} \rightarrow \mathrm{SmA}$ & $83^{[a]}$ & - & - & - \\
\hline & $\mathrm{SmA} \rightarrow \mathrm{G}$ & 17 & 1.46 & - & - \\
\hline \multirow[t]{2}{*}{$\left(n \mathrm{Bu}_{4} \mathrm{~N}\right)_{2}\left[\mathrm{Mo}_{6} \mathrm{Br}_{8} \mathrm{~L}_{6}^{3,4}\right]$} & $\mathrm{I} \rightarrow \mathrm{SmA}$ & 103 & - & 24.3 & 2.03 \\
\hline & $\mathrm{SmA} \rightarrow \mathrm{G}$ & 20 & 1.52 & - & - \\
\hline
\end{tabular}

the $2^{\text {nd }}$ heating cycle.

[a] These values represent the temperatures taken from microscopy, [b] Combined enthalpies, [c] in kJ.mol-1.K$1,[\mathrm{~d}]$ in $\mathrm{kJ}^{\mathrm{mol}}{ }^{-1}$ 

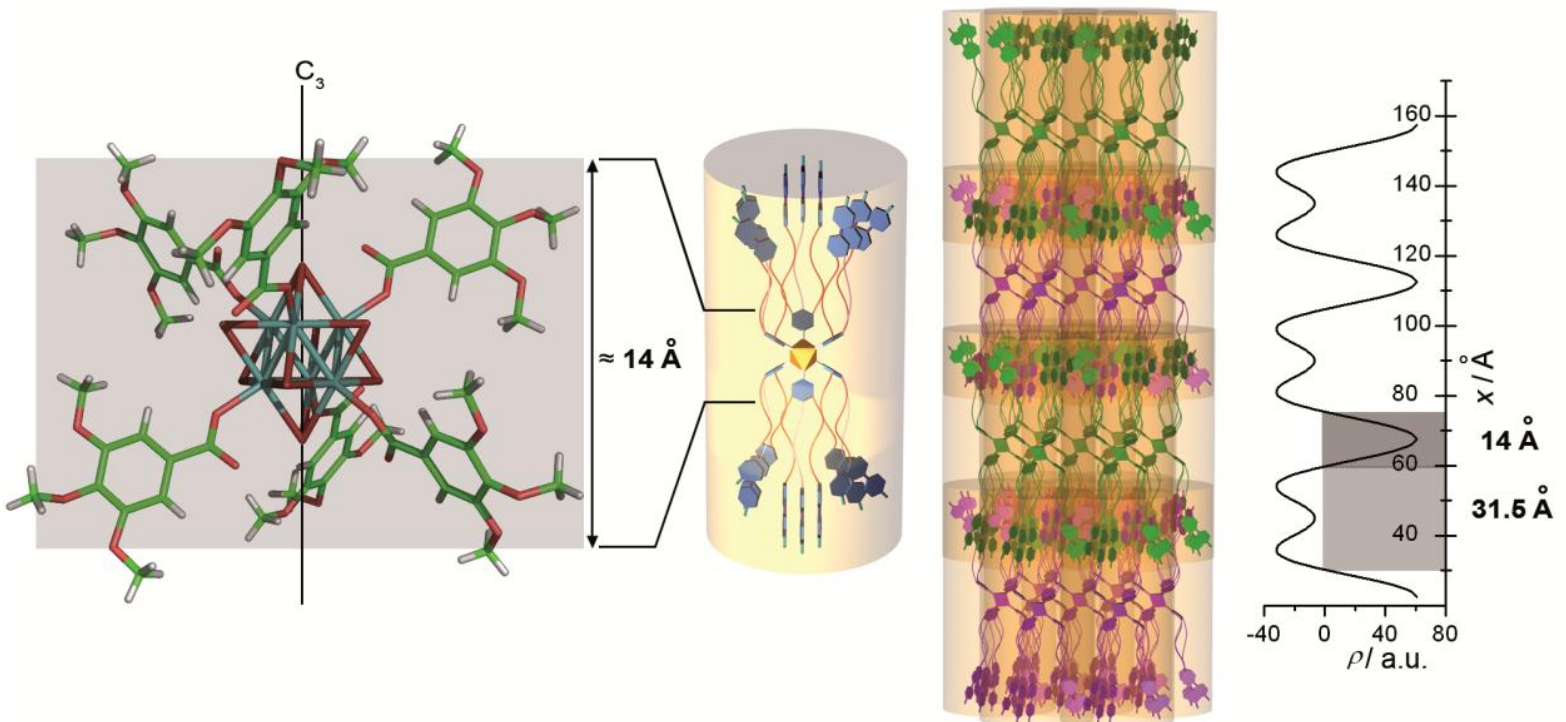

Fig. 5 Representation of the $\left[\mathrm{Mo}_{6} \mathrm{Br}_{8} \mathrm{~L}_{6}^{1}\right]^{2-}$ building block according to single crystal X-Ray diffraction analysis of $\left(n \mathrm{Bu}_{4} \mathrm{~N}\right)_{2}\left[\mathrm{Mo}_{6} \mathrm{Br}_{8} \mathrm{~L}_{6}^{1}\right]$-xHF,1THF (left side) and illustration of the lamellar packing in the smectic X layer of $\left(n \mathrm{Bu}_{4} \mathrm{~N}\right)_{2}\left[\mathrm{Mo}_{6} \mathrm{Br}_{8} \mathrm{~L}_{6}^{2}\right]-6 \mathrm{HF}$ along the $C_{3}$ axis of the clusters according to the calculated electronic density profile (right side). $\left(\mathrm{nBu}_{4} \mathrm{~N}\right)^{+}$cations and $\mathrm{HF}$ molecules are omitted for clarity. Reprinted with permission from [76].

In parallel, inorganic matrix could be used instead of polymer for the incorporation of $\mathrm{Mo}_{6}$ nanosized cluster units. Recently, we described the preparation and characterization of photonic colloidal crystals based on silica spheres with incorporated luminescent $\left[\mathrm{Mo}_{6} \mathrm{Br}_{14}\right]^{2-}$ cluster units (Figure 6).
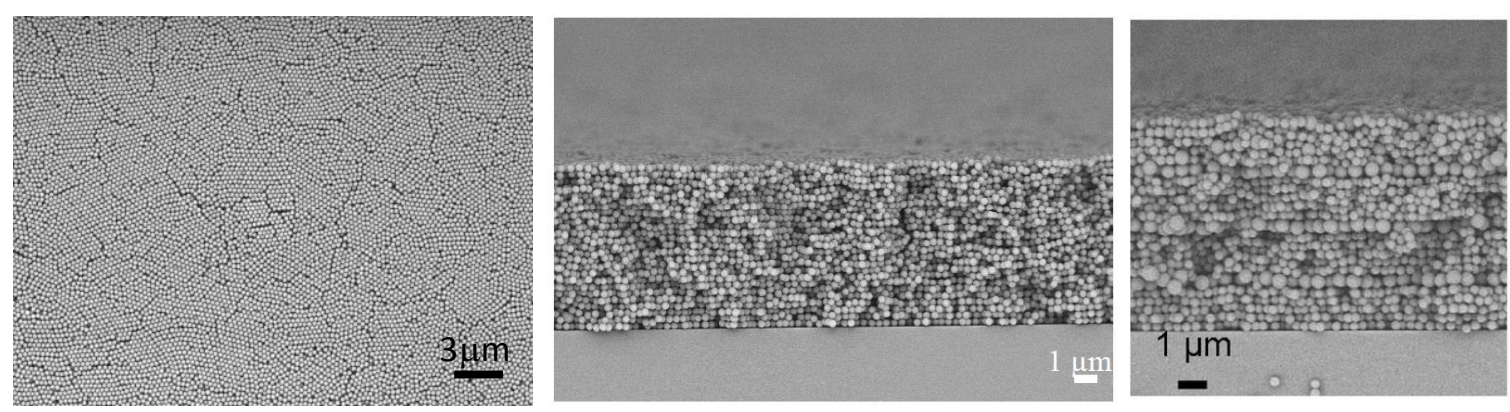

Fig. 6 (left) SEM top view of a photonic colloidal crystal composed of one layer of $460 \mathrm{~nm} \mathrm{Cs}_{2} \mathrm{Mo}_{6} \mathrm{Br}_{14} @ \mathrm{SiO}_{2}$ spheres embedded between two stacks of five layers of $330 \mathrm{~nm} \mathrm{Cs} \mathrm{Mo}_{6} \mathrm{Br}_{14} @ \mathrm{SiO}_{2}$ particles (middle) SEM side view of a photonic colloidal crystal composed of 25 layers of $330 \mathrm{~nm} \mathrm{Cs} \mathrm{Mo}_{6} \mathrm{Br}_{14} @ \mathrm{SiO}_{2}$ particles; (right) SEM side view of an A(BA)3 heterostructure. ([82] Reproduced with permission of the PCCP Owner Societies).

These new materials were synthesized by using the Langmuir-Blodgett technique [79-81]. The photonic crystals fabricated with the $\mathrm{Cs}_{2} \mathrm{Mo}_{6} \mathrm{Br}_{14} @ \mathrm{SiO}_{2}$ particles display a strong iridescence in the visible region of the spectrum, which indicates the presence of a photonic stopband due to the regular ordering of the building spherical units [82]. The good crystalline 
quality of a crystal made of 25 layers of $330 \mathrm{~nm}$ particles can be seen on the SEM views shown in Fig. 6. The successful engineering of the crystal was clearly demonstrated, as the pseudo-gap maximum overlaps completely or partially with the emission band of the $\mathrm{Cs}_{2} \mathrm{Mo}_{6} \mathrm{Br}_{14} @ \mathrm{SiO}_{2}$ particles. This structure exhibit strong angle-dependent luminescent properties as observed on the optical extinction/reflection spectra of the crystal (solid lines), taken at various incidence angles (Figure 7).

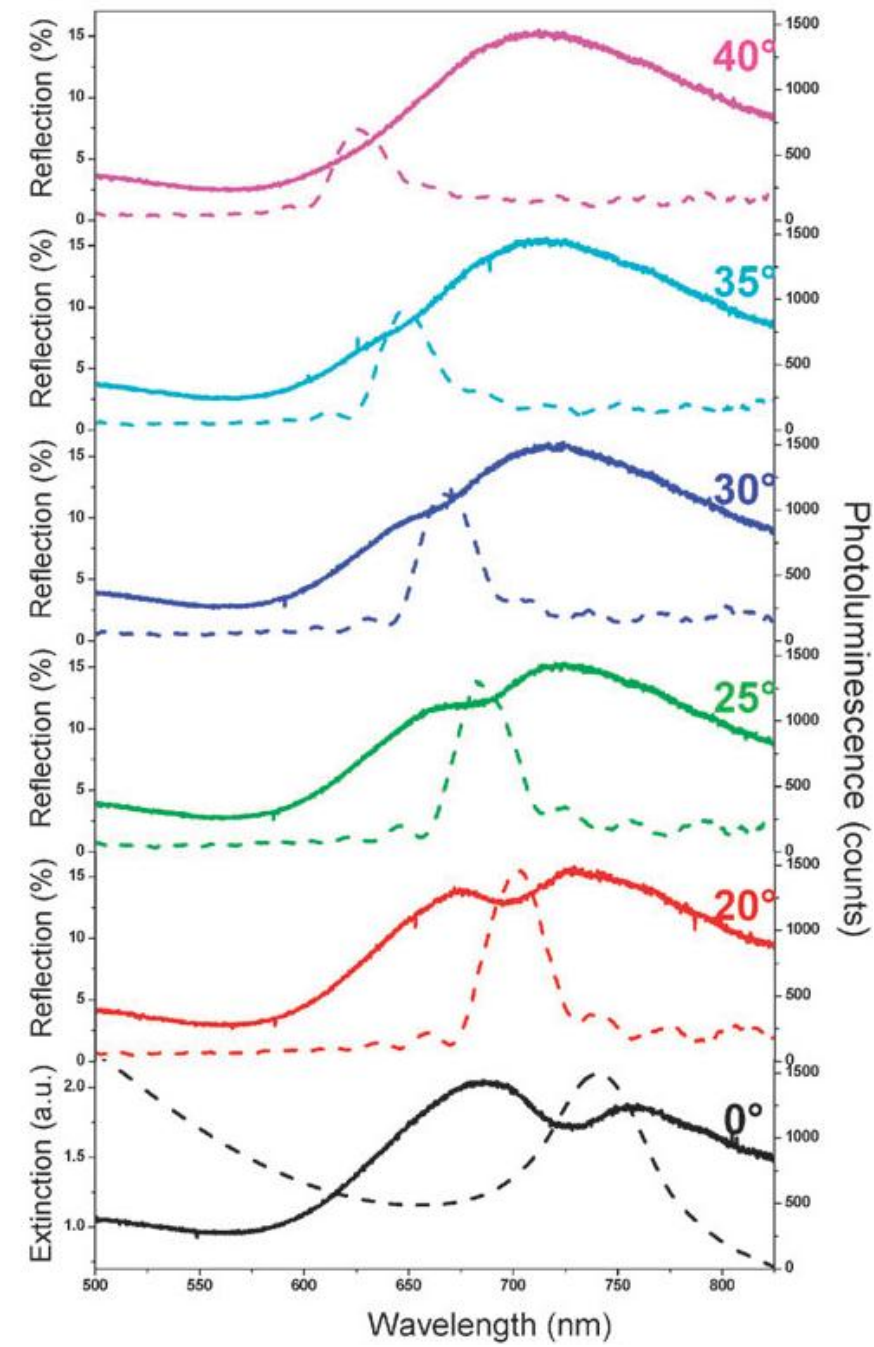

Fig. 7 Angle dependence of the extinction (at $\alpha=0^{\circ}$ )/reflection (for larger angles) and corresponding photoluminescence spectra of the engineered colloidal structure. ([82] Reproduced with permission of the PCCP Owner Societies).

We have also engineered a photonic heterostructure made by alternated deposition of stacks (A) made of five layers of $330 \mathrm{~nm} \mathrm{Cs}_{2} \mathrm{Mo}_{6} \mathrm{Br}_{14} @ \mathrm{SiO}_{2}$ particles with one monolayer (B) of $460 \mathrm{~nm} \mathrm{Cs} \mathrm{Mo}_{6} \mathrm{Br}_{14} @ \mathrm{SiO}_{2}$ particles. Figure 6 (right) shows a SEM side view of an A(BA)3 heterostructure. The insertion of the defect layers induces the appearance of localized states for photons within the L pseudo-gap of the host particles structure. Accordingly, a passband is 
created within the stopband (Figure 8). On the basis of the particle diameters of the guest and host particles used for the preparation of the sample, the passband position is expected to overlap the emission profile of the colloidal building units. In the energy range of this passband, an increase of the emission intensity has been found. Heterostructures containing one $\left(\mathrm{A}(\mathrm{AB})_{1}\right)$ or three $\left(\mathrm{A}(\mathrm{AB})_{3}\right)$ planar defects displayed increased emission in the spectral region of the passband (Figure 8 ).

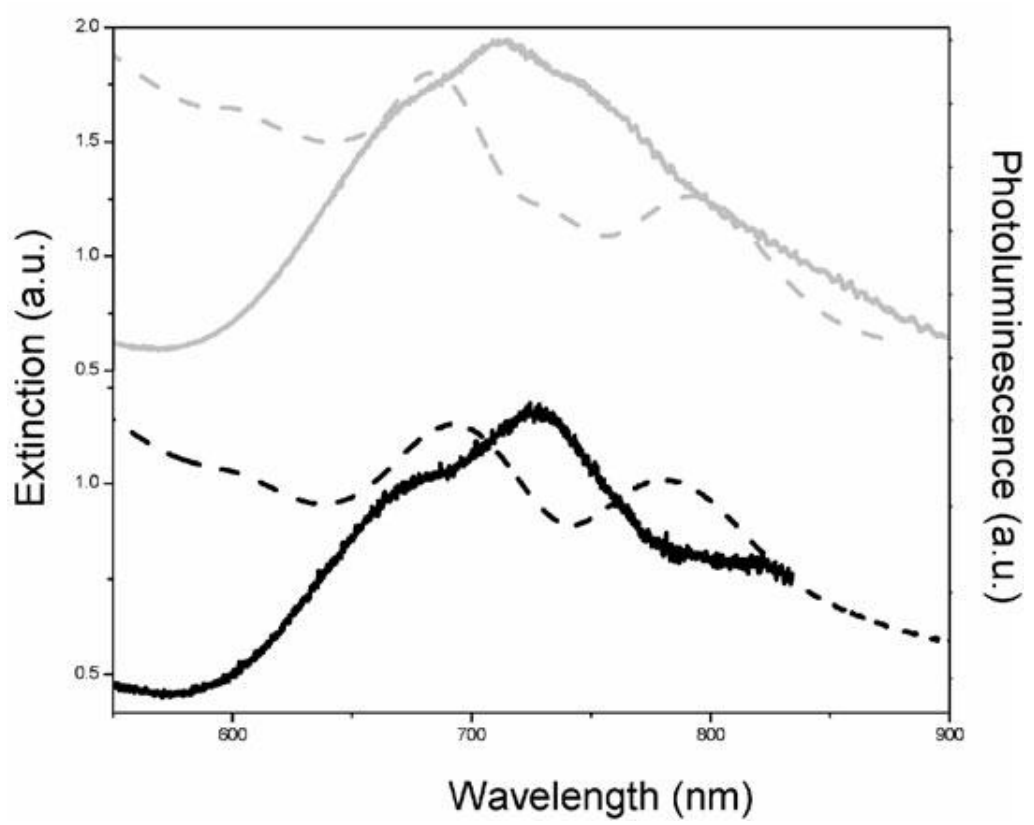

Fig. 8 Experimental extinction (at $\alpha=0^{\circ}$ ) (dashed lines) and photoluminescence spectra (solid lines) of the $\mathrm{A}(\mathrm{BA})_{1}$ (black curves) and $\mathrm{A}(\mathrm{BA})_{3}$ (grey curves) heterostructures. Spectra are vertically shifted for better clarity. ([82] Reproduced with permission of the PCCP Owner Societies).

The 3D photonic colloidal structures investigated are very promising for both basic and applied research related to the confinement and exaltation of spontaneous emission in given frequency ranges and thus are good candidates for low-threshold and/or single mode photonic crystal lasers.

\section{New nanostructured materials based on Mo Nanocluster for nanobiotechnology applications:}

Among the arising nanobiotechnologies, multifunctional nanoparticles with complex architecture (Figure 9) constitute one of the most promising and studied research fields [83]. 


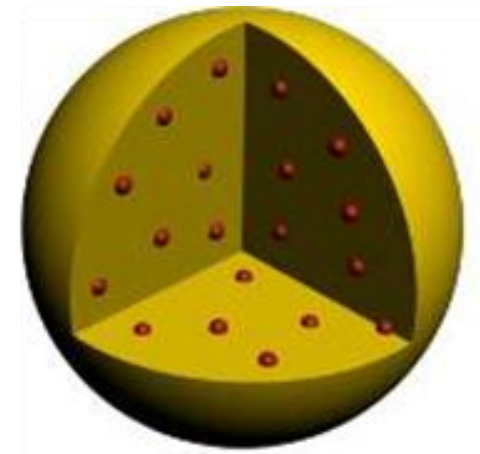

homogeneous

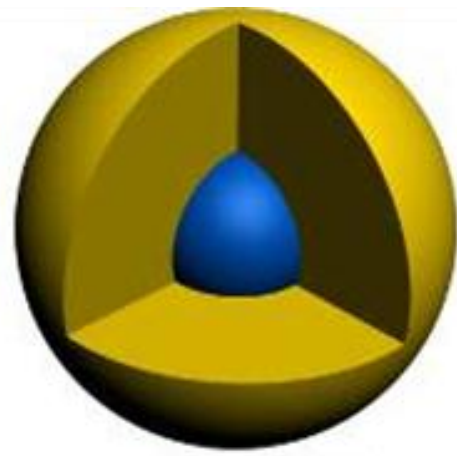

core-shell

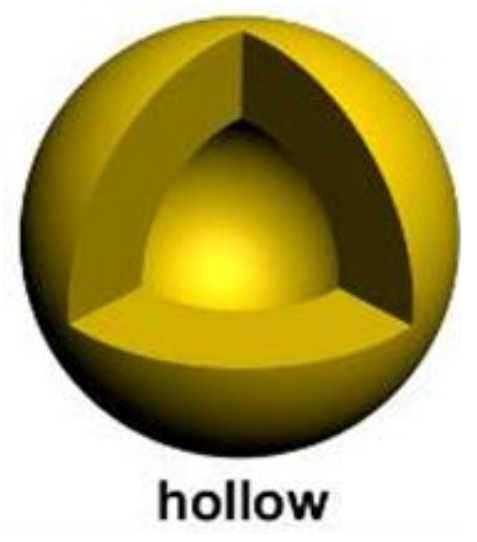

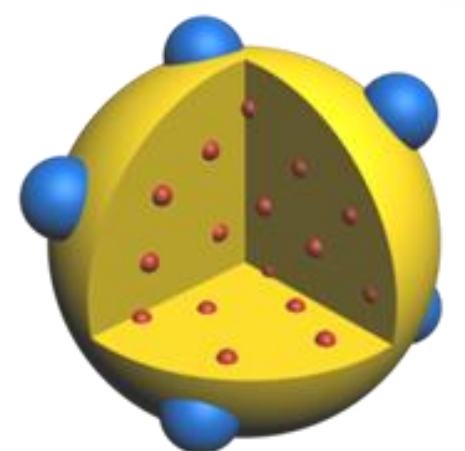

bi-functional

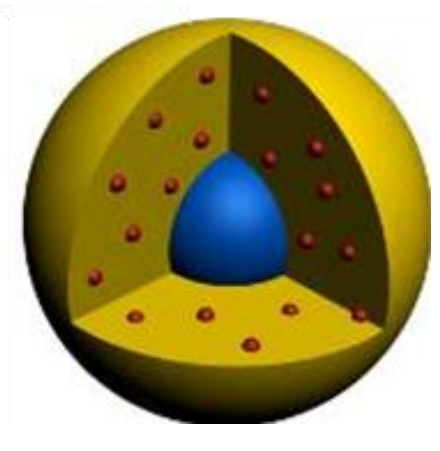

bi-functional

Fig. 9 Multifunctional nanoparticles with complex architecture.

Supramolecular materials focusing on gene and drug delivery [84], inorganic luminescent silica nanoparticles for bioimaging [85], superparamagnetic iron oxide nanoparticles as contrast agents for magnetic resonance imaging (MRI) or colloidal mediators for cancer magnetic hyperthermia [86] find numerous applications in the field of nanobiotechnology. Recently, we demonstrated that metal atom clusters (Mo, Re) could play a significant role for near infra-red (NIR) bioimaging application [87, 88]. During the last decade, we developed a simple, versatile and efficient method based on silica nanoparticles incorporating luminescent nanosized $\mathrm{Mo}_{6}$ cluster units $[18,87,89-92]$. The $\mathrm{Mo}_{6}$ metal atom nanosized cluster units exhibit a broad emission band in the red and NIR (550-900 nm) centered at $720 \mathrm{~nm}$ [93], which is particularly interesting for biotechnology applications as it corresponds to a low absorption of human tissues at these wavelengths [94]. Moreover, they generate singlet oxygen under irradiation, which is of particular interest for photodynamic therapy (PDT) and for other applications of singlet oxygen [95]. Thus, thanks to the very good reproducibility of their synthesis in large amounts, these nanocluster units may represent a complementary alternative to traditional Vis-NIR luminophores (organic dyes, QDs or lanthanide-based nanocrystals) developed for bioimaging and biolabeling [96-100]. The nanoparticles have 
been prepared using a water-in-oil (W/O) microemulsion process developed by our group since 2000 [101, 102]. Microemulsions are thermodynamically stable dispersions of two immiscible fluids stabilized by the arrangement of surfactant molecules at the interface [103]. The W/O microemulsions consist of nanodroplets of pseudo-water phase dispersed in an oil phase and stabilized in spherical reverse micelles created by the surfactant molecules. Those water droplets can then be considered as nanoreactors and by controlling the molar ratio of the mixture oil/water/surfactant, it is possible to predetermine the size and shape of those droplets and, as a consequence, to tailor the size and shape of the final silica nanoparticles [see review 104, 105]. Thanks to this W/O microemulsion process, the $\mathrm{Mo}_{6}$ cluster units were efficiently encapsulated in the silica nanoparticles with a good stability [87, 89-92, 105].
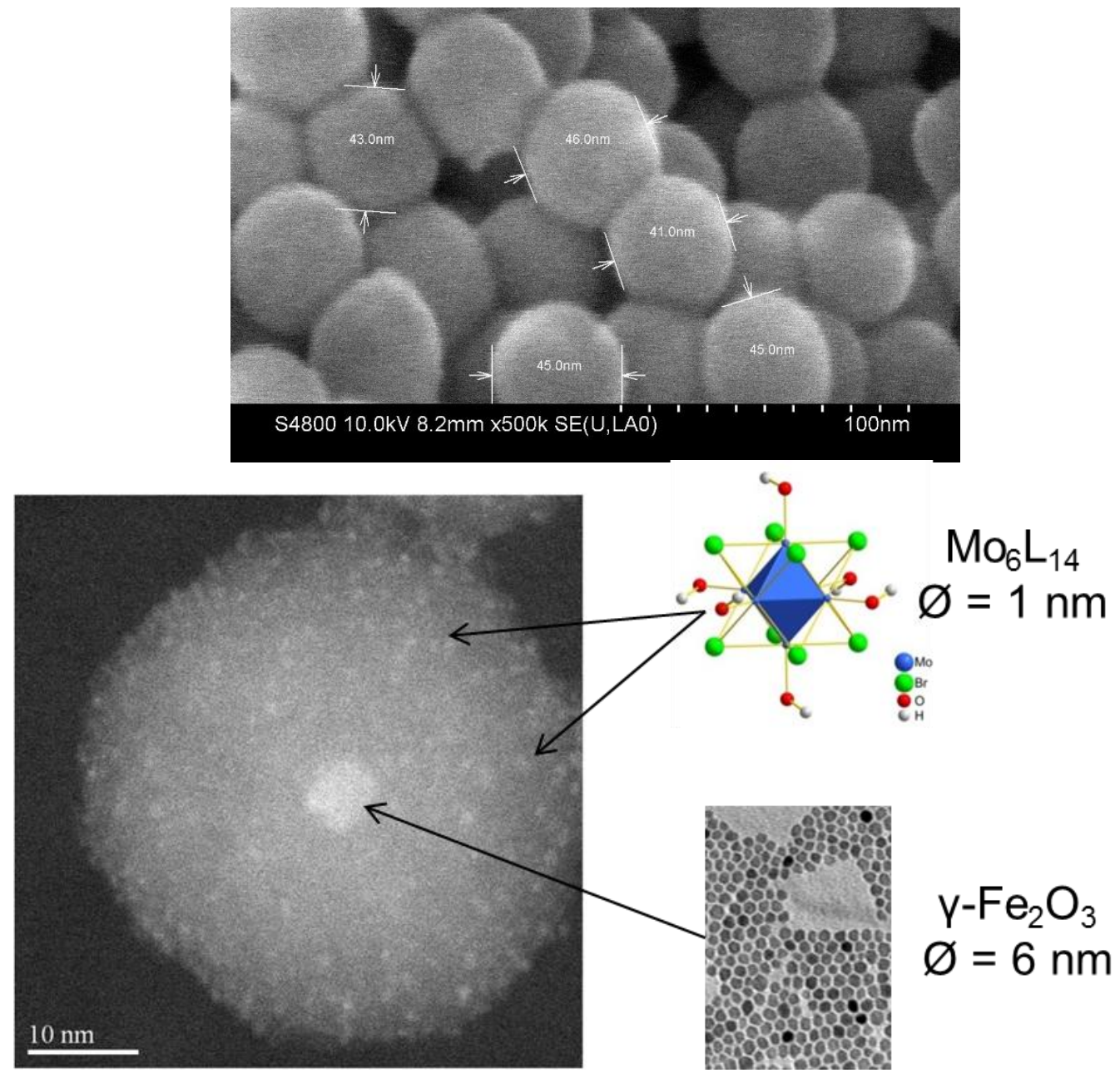

Fig. $10 \mathrm{SEM}$ image of $\mathrm{Cs}_{2}\left[\mathrm{Mo}_{6} \mathrm{Br}_{14}\right] @ \mathrm{SiO}_{2}$ nanoparticles (upper) and HAADF-STEM images of $\left[\mathrm{Cs}_{2} \mathrm{Mo}_{6} \mathrm{Br}_{14^{-}}\right.$ $\left.\chi \mathrm{Fe}_{2} \mathrm{O}_{3}\right] @ \mathrm{SiO}_{2}$ with magnetic core size of $6 \mathrm{~nm}$ (lower).

The concentration of cluster units could be adjusted without affecting the size and morphology of the silica nanoparticles. Large amount of monodispersed functional silica nanoparticles with a size below $50 \mathrm{~nm}$ can be easily produced by this technique (Figure 10). 
Recently, it has been proved that during the encapsulation process, the cluster units are chemically modified as they lose their apical $\mathrm{Br}$ ligands and roughly half of their $\mathrm{Cs}^{+}$counter cations [91]. This loss of ligands resulted in a slight modification of the optical properties of the $\mathrm{Cs}_{2}\left[\mathrm{Mo}_{6} \mathrm{Br}_{14}\right] @ \mathrm{SiO}_{2}$ nanoparticles with in particular a blue shift of the maximum of emission. These $\mathrm{Br}$ ligands are most probably exchanged partially by $\mathrm{OH}$ groups that can form hydrogen bonds with the silanol groups of the silica and by OSi groups through a covalent bonding between the cluster units and the silica matrix, leading to a cluster compound with the following formula: $\left(\mathrm{Cs}, \mathrm{NH}_{4}\right)-\left[\mathrm{Mo}_{6} \mathrm{Br}_{8}^{\mathrm{i}}(\mathrm{OSi})_{6-\mathrm{x}}^{\mathrm{a}}(\mathrm{OH})_{\mathrm{x}}^{\mathrm{a}}\right]$, with $\mathrm{x}$ being between 0 and 6. An important feature of these nanoparticles is that the silica matrix protects, to some extent, the cluster units from the presence of oxygen in solution and the nanoparticles remain luminescent even when dispersed in water and in wide range of $\mathrm{pH}$ (Figure 11) in contrary to QDs [99].
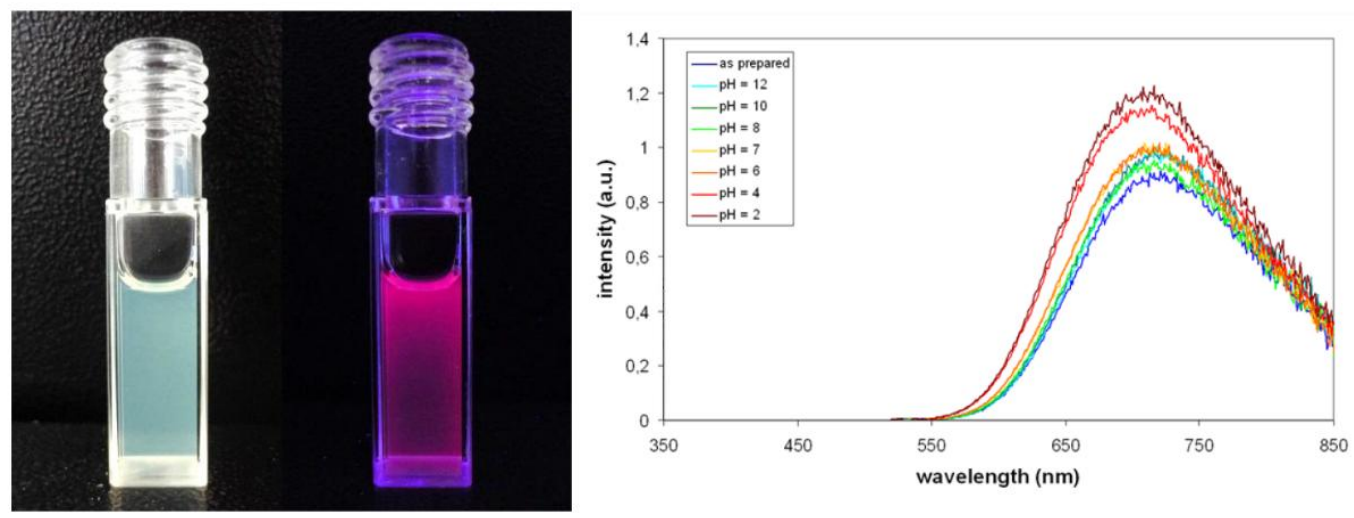

Fig. 11 Left: Photographs of a $\mathrm{Cs}_{2}\left[\mathrm{Mo}_{6} \mathrm{Br}_{14}\right] @ \mathrm{SiO}_{2}$ colloid in water under daylight (a) and under UV excitation at $365 \mathrm{~nm}$ (b). Right: Emission spectra of $\mathrm{a} \mathrm{Cs}_{2}\left[\mathrm{Mo}_{6} \mathrm{Br}_{14}\right] @ \mathrm{SiO}_{2}$ colloid in water at different pH (from 2 to 12).

Lifetime measurements of $\left[\mathrm{Mo}_{6} \mathrm{Br}_{14}\right]^{2-}$ incorporated into $\mathrm{SiO}_{2}$ nanoparticles were reported in solid state and in solution conditions revealed a long (100-50 $\mu$ s), and a short component (30$8.5 \mu \mathrm{s})[66,87$ and 92]. Experiments of time-gated detection of long-lifetime (1-2000 $\mu \mathrm{s})$ luminescence-labeled microorganisms are in progress. Regarding cyto(and eco)toxicity, our results indicate that $\mathrm{Cs}_{2}\left[\mathrm{Mo}_{6} \mathrm{Br}_{14}\right] @ \mathrm{SiO}_{2}$ nanoparticles do not show any significant toxic effect on the growth and morphology of plants. For cytotoxicity, we observed a dosedependence effect at very high doses but no time-dependence effect. This preliminary toxicity test will be soon completed by further studies and will be the topic of a next publication. 
Based on these results, $\mathrm{Mo}_{6}$ clusters based silica nanoparticles should be relevant tools for theranostic applications.

\section{New nanostructured materials based on Mo $\mathrm{Mo}_{6}$ Nanocluster for Energy and Environemental applications:}

Supramolecular hybrid organic-inorganic frameworks. In term of nanoarchitectonics, $\left[\mathrm{Mo}_{6} \mathrm{X}_{8}^{\mathrm{i}} \mathrm{X}_{6}^{\mathrm{a}}\right]^{2-}$ units are relevant building blocks for the design of organic frameworks exhibiting electronic transport properties. Indeed, beyond interesting luminescent properties, $\left[\mathrm{Mo}_{6} \mathrm{X}_{8}^{\mathrm{i}} \mathrm{X}_{6}^{\mathrm{a}}\right]^{2-}$ units can be used as structuring moieties for the organization of flat molecules including a variety of tetrathiafulvalene derivatives or coronene molecules in charge-transfer solids under crystalline form (single crystals or powders) [106-108]. The resulting charge transfer salts exhibit fascinating crystal structures with a variety of intriguing and/or unprecedented packing patterns and electronic structures of the organic cationic frameworks, leading for instance to special magnetic or Mott-insulating behaviors. These original structural and physical properties originate from the bulkiness of the cluster unit (between 12 and $14 \AA$ in diameter depending on the nature of the halogen) and from the cluster hydrogen bonding abilities. The structuring of the materials occurs thus at the nanometric scale by selfassembling of $\mathrm{Mo}_{6}$ cluster units with organic cations. One of the most promising results concerning this field is the association of $\left[\mathrm{Mo}_{6} \mathrm{Cl}_{8}^{\mathrm{i}} \mathrm{Cl}_{6}^{\mathrm{a}}\right]^{2-}$ with coronene cations to form (coronene) ${ }_{3} \mathrm{Mo}_{6} \mathrm{Cl}_{14}$ salt characterized by a novel isotropic $3 \mathrm{D} \pi$-system. A challenging outlook is the exploration of isotropic molecular solids composed of doubly-charged coronene cations by using tailor-made cluster units. Indeed, the half-filled doubly degenerate HOMO state [109] may allow exotic properties such as high-Tc superconductivity. The ability of the cluster unit to form supramolecular bonding is governed by the polarization of the Mo- $\mathrm{L}^{\mathrm{i}}$ and Mo- $\mathrm{L}^{\mathrm{a}}$ bonds. As a rule, the Mo- $\mathrm{L}^{\mathrm{i}}$ bond is more covalent and less polarized than the Mo- $\mathrm{L}^{\mathrm{a}}$ bond. The driving force to form a 3D-network of coronene in (coronene) ${ }_{3} \mathrm{Mo}_{6} \mathrm{Cl}_{14}$ is the formation of $\mathrm{Cl}^{\mathrm{a}} \cdots \mathrm{H}-\mathrm{C}$ hydrogen bonds.

Fluorinated clusters for hydrogen storage applications. Playing with the nature of inner and apical halogen should enable to tune the chemical affinity of $\left[\mathrm{Mo}_{6} \mathrm{Br}_{8}{ }_{8} \mathrm{~F}_{6}^{\mathrm{a}}\right]^{2-}$ with its environment. For instance, $\left[\mathrm{Mo}_{6} \mathrm{Br}_{8}^{\mathrm{i}} \mathrm{F}_{6}^{\mathrm{a}}\right]^{2-}$ cluster unit possesses highly polarized Mo-F bonds as potential strong interactions sites for hydrogen. It was shown that apical fluorine enables a greater stabilization of bonding orbitals in $\left[\mathrm{Mo}_{6} \mathrm{Br}_{8}{ }_{8} \mathrm{~F}_{6}^{\mathrm{a}}\right]^{2-}$ units and a higher HOMO-LUMO 
energy gap than apical chlorine or bromine and to a greater extent than iodine atoms. This effect is directly related to the very poor $\pi$-donor character of fluorine compared to other halogen ligands. The enhanced stabilization of the metal-fluorine bond is due to a higher electrostatic interaction component as already demonstrated for other metal halide complex series. Indeed, the Mo- $\mathrm{F}^{\mathrm{a}}$ bond exhibits a strong ionic character compared to $\mathrm{Mo}-\mathrm{Cl}^{\mathrm{a}}, \mathrm{Mo}-\mathrm{Br}^{\mathrm{a}}$, and Mo-I ${ }^{\mathrm{a}}$ bonds. Fluorinated $\left[\mathrm{Mo}_{6} \mathrm{Br}_{8}^{\mathrm{i}} \mathrm{F}_{6}^{\mathrm{a}}\right]^{2-}$ cluster unit was included within the pores of MIL-101 in order to evaluate -as a model system- the change in the room temperature hydrogen storage efficiency of metal organic frameworks (MOF) [110]. MOF are known to combine porosity of the crystal architecture with particular physical properties of metal ions or organic molecules building these crystal architectures. Among MOF, MIL-101 (or $\mathrm{Cr}_{3} \mathrm{~F}\left(\mathrm{H}_{2} \mathrm{O}\right)_{2} \mathrm{O}\left[\mathrm{C}_{6} \mathrm{H}_{4}-\left(\mathrm{CO}_{2}\right)_{2}\right]_{3}$; MIL for Matériau Institut Lavoisier) $[111,112]$ is one of the most studied mesoporous material for its catalytic and gas adsorption properties. It is built up from 1,4-benzenedicarboxylate moieties and chromium(III) trimeric oxocentered subunits to produce large hybrid supertetrahedra. It results in a mesoporous zeotype architecture having a huge cell volume (702 $000 \AA^{3}$ ) with two types of mesoporous cages of free diameters close to 29 and $34 \AA$ A. After careful activation, the resulting Brunauer-Emmett-Teller, (BET) surface area and pore volume are close to $4200 \mathrm{~m}^{2} \mathrm{~g}^{-1}$ and $2.15 \mathrm{~g} \mathrm{~cm}^{-3}$, respectively. This material possesses very large pores that would not seem suitable for providing sufficient interactions with hydrogen molecules. Its hydrogen uptake was to some extent rather disappointing with a hydrogen sorption capacity of $6.1 \mathrm{wt} \%$ at $77 \mathrm{~K}$ and $6 \mathrm{MPa}$ or $0.4 \mathrm{wt} \%$ at $298 \mathrm{~K}$ and $10 \mathrm{MPa}$. Incorporation of the clusters within the pores of MIL-101 (Figure 12) was performed by dispersion of both the dried MIL-101 solid and the cluster in a mixture of ethanol and a small amount of aqueous solution of fluorhydric acid, in order to prevent partial cluster hydrolysis. Hydrogen sorption experiments were performed on the MIL-101 and the MIL-101- $\mathrm{Mo}_{6} \mathrm{Br}_{8} \mathrm{~F}_{6}$ in two pressure regions. By incorporation of the metal clusters, the gravimetric hydrogen storage capacity is reduced strongly. 


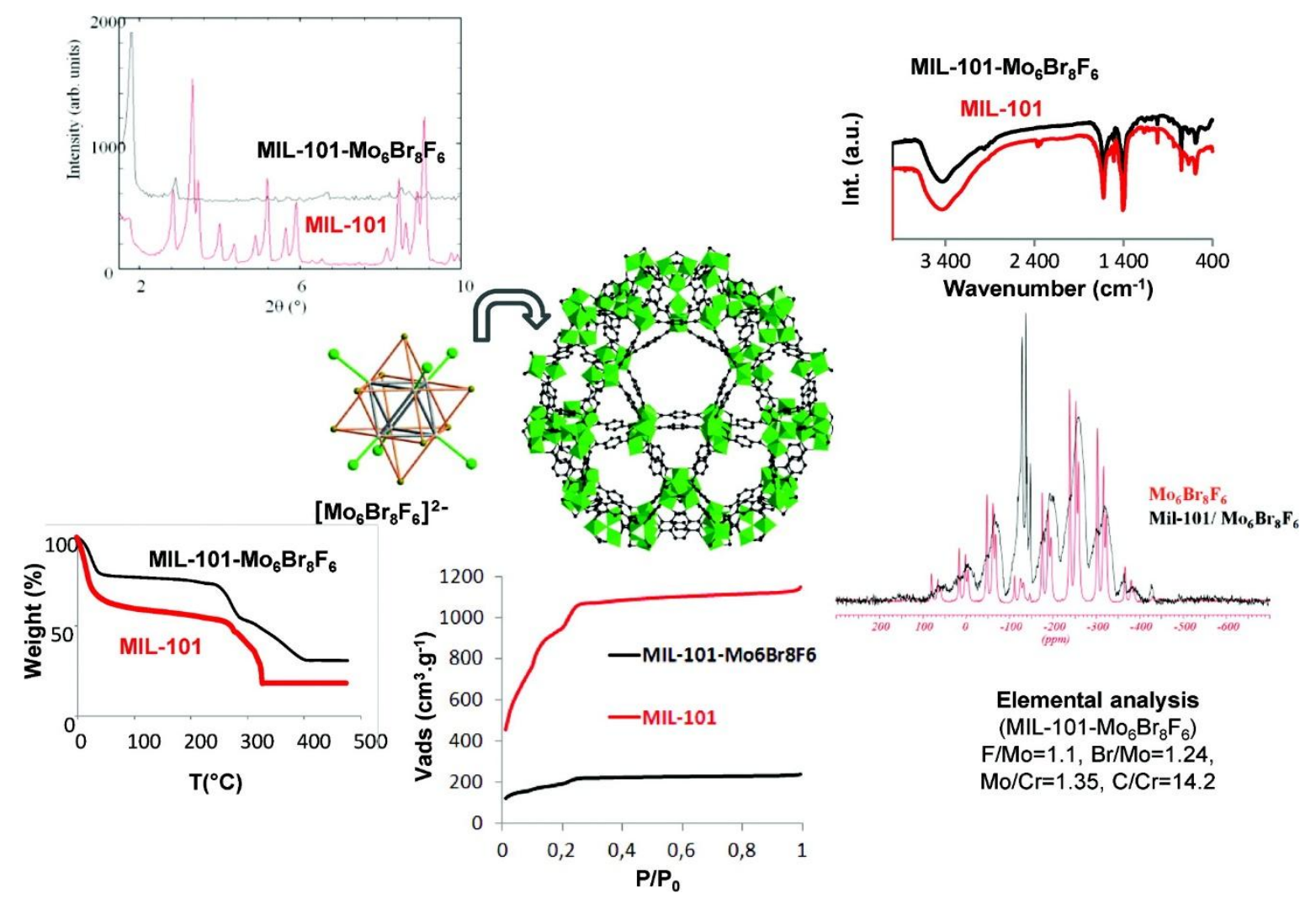

Fig. 12 (center) Schematic view of the inclusion of the $\left[\mathrm{Mo}_{6} \mathrm{Br}_{8} \mathrm{~F}_{6}\right]^{2-}$ cluster units within the pores of MIL-101; clockwise, the different analyses proving the incorporation of the cluster within MIL-101: (a) ${ }^{19}$ F NMR MAS spectra, experimental (blue line) and simulated (red line), of (TBA) ${ }_{2} \mathrm{Mo}_{6} \mathrm{Br}_{8} \mathrm{~F}_{6}$ (bottom) and $\mathrm{MIL}-101-\mathrm{Mo}_{6} \mathrm{Br}_{8} \mathrm{~F}_{6}$ (top); (b) IR spectra of MIL-101 and MIL-101- $\mathrm{Mo}_{6} \mathrm{Br}_{8} \mathrm{~F}_{6}$; (c) X-ray powder diffraction of MIL-101 and MIL$101-\mathrm{Mo}_{6} \mathrm{Br}_{8} \mathrm{~F}_{6}$; (d) TGA under air atmosphere of MIL-101 and MIL-101- $\mathrm{Mo}_{6} \mathrm{Br}_{8} \mathrm{~F}_{6}$; (e) nitrogen sorption isotherms at $77 \mathrm{~K}$ of MIL-101 and MIL-101- $\mathrm{Mo}_{6} \mathrm{Br}_{8} \mathrm{~F}_{6}(P 0=1 \mathrm{~atm})$. Reprinted with permission from [110]. Copyright $\{2010\}$ American Chemical Society.

Due to the increase in crystal density from MIL-101 to MIL-101- $\mathrm{Mo}_{6} \mathrm{Br}_{8} \mathrm{~F}_{6}$, a comparison of the hydrogen uptake per volume behavior of MIL-101 and MIL-101- $\mathrm{Mo}_{6} \mathrm{Br}_{8} \mathrm{~F}_{6}$ is more evocative for the uptake at $77 \mathrm{~K}$ up to $0.6 \mathrm{MPa}$. At pressures beyond $0.35 \mathrm{MPa}$, the volumetric hydrogen storage capacity was increased by up to $20 \%$ by the inclusion of the metal clusters. At room temperature and $8 \mathrm{MPa}$, the hydrogen storage capacity of the MIL$101-\mathrm{Mo}_{6} \mathrm{Br}_{8} \mathrm{~F}_{6}$ is over twice that of MIL-101. This enhanced hydrogen uptake may be assigned to higher heat of adsorption for hydrogen in MIL-101- $\mathrm{Mo}_{6} \mathrm{Br}_{8} \mathrm{~F}_{6}$. The highly polarized Mo- $\mathrm{F}^{\mathrm{a}}$ is explained by the steric hindrance of inner ligands that do not favor covalent interactions between Mo and F. The challenge in view of applications will consist now to tailor made fluorinated metal atom clusters with lower molecular weight than $\left[\mathrm{Mo}_{6} \mathrm{Br}_{8}^{\mathrm{i}} \mathrm{F}_{6}^{\mathrm{a}}\right]^{2-6}$ as for instance $\left[\mathrm{Cr}_{2} \mathrm{~F}_{3}^{\mathrm{i}} \mathrm{F}_{3}^{\mathrm{a}}\right]^{3-}$ units [113-115]. The latter will have two 
advantages: (i) chromium is lighter than molybdenum and (ii) the fluorine/metal ratio is 4.5 for $\left[\mathrm{Cr}_{2} \mathrm{~F}_{9}\right]^{3-}$ against 1 in $\left[\mathrm{Mo}_{6} \mathrm{Br}_{8}{ }^{\mathrm{i}} \mathrm{F}_{6}^{\mathrm{a}}\right]^{2-}$.

Metal to ligands charge transfers and photocatalytic applications. In molecular assemblies based on $\left(\mathrm{Mo}_{6} \mathrm{X}_{8}^{\mathrm{i}}\right)^{4+}$ cluster core and TTF-CH=CH-Py ligands (TTF = tetrathiafulvalene; $\mathrm{Py}=$ pyridine; $\mathrm{X}=\mathrm{Cl}, \mathrm{Br}, \mathrm{I})$ [116], synergetic $\pi$-d interactions between the organic ligands and the cluster core were experimentally evidenced by electrochemistry and absorption measurements and corroborated by DFT calculations. Moreover, a direct $\mathrm{M}_{6} \mathrm{X}_{8}^{\mathrm{i}}$ cluster core-to-ligand charge-transfer excited state was observed in an octahedral hexarhenium unit namely $\left[\operatorname{Re}_{6} \mathrm{~S}_{8}^{\mathrm{i}} \mathrm{Cl}_{5}^{\mathrm{a}}{ }_{5} \mathrm{ppy}^{\mathrm{a}}\right]^{3-}$ (ppy = 4-phenylpyridine) [117]. Such electronic transfers are mandatory for photocatalytic activities. Moreover, for $\left(\mathrm{Mo}_{6} \mathrm{X}_{8}^{\mathrm{i}}\right)^{4+}$ cluster core absorbing efficiently UV and visible light $\left(E_{\mathrm{g}}\right.$ around $\left.2 \mathrm{eV}\right)$, it was very interesting to test their photocatalytic activities for comparison with other semiconductor materials. To achieve this goal, first tests were performed in water and since $\left[\mathrm{Mo}_{6} \mathrm{X}_{8}^{\mathrm{i}} \mathrm{X}_{6}^{\mathrm{a}}\right]^{2-}$ units hydrolyze to form rapidly aqua hydoxo complexes, the tests were performed using water stable $\left[\mathrm{Mo}_{6} \mathrm{X}_{8}^{\mathrm{i}}\left(\mathrm{N}_{3}\right)_{6}^{\mathrm{a}}\right]^{2-}$ cluster unit [118]. It was shown that $\left[\mathrm{Mo}_{6} \mathrm{Br}_{8}\left(\mathrm{~N}_{3}\right)_{6}\right]^{2-}$ cluster unit exhibits excellent photocatalytic performance for the decomposition of rhodamine $\mathrm{B}(\mathrm{RhB})$ under $\mathrm{UV}$ and visible light irradiation [119]. A photocatalyst concentration in the range of $20-30 \mathrm{mg} \mathrm{L}^{-1}$ of the $\mathrm{Na}_{2}\left[\mathrm{Mo}_{6} \mathrm{Br}_{8}\left(\mathrm{~N}_{3}\right)_{6}\right]$ cluster precursor was found to be optimal for $\mathrm{RhB}$ degradation even though the mechanism seems to be wavelength dependent. Furthermore, experiments run under real solar light excitation suggest that the molybdenum cluster could be an efficient catalyst to decompose organic pollutants in broad daylight hours (Figure 13). 

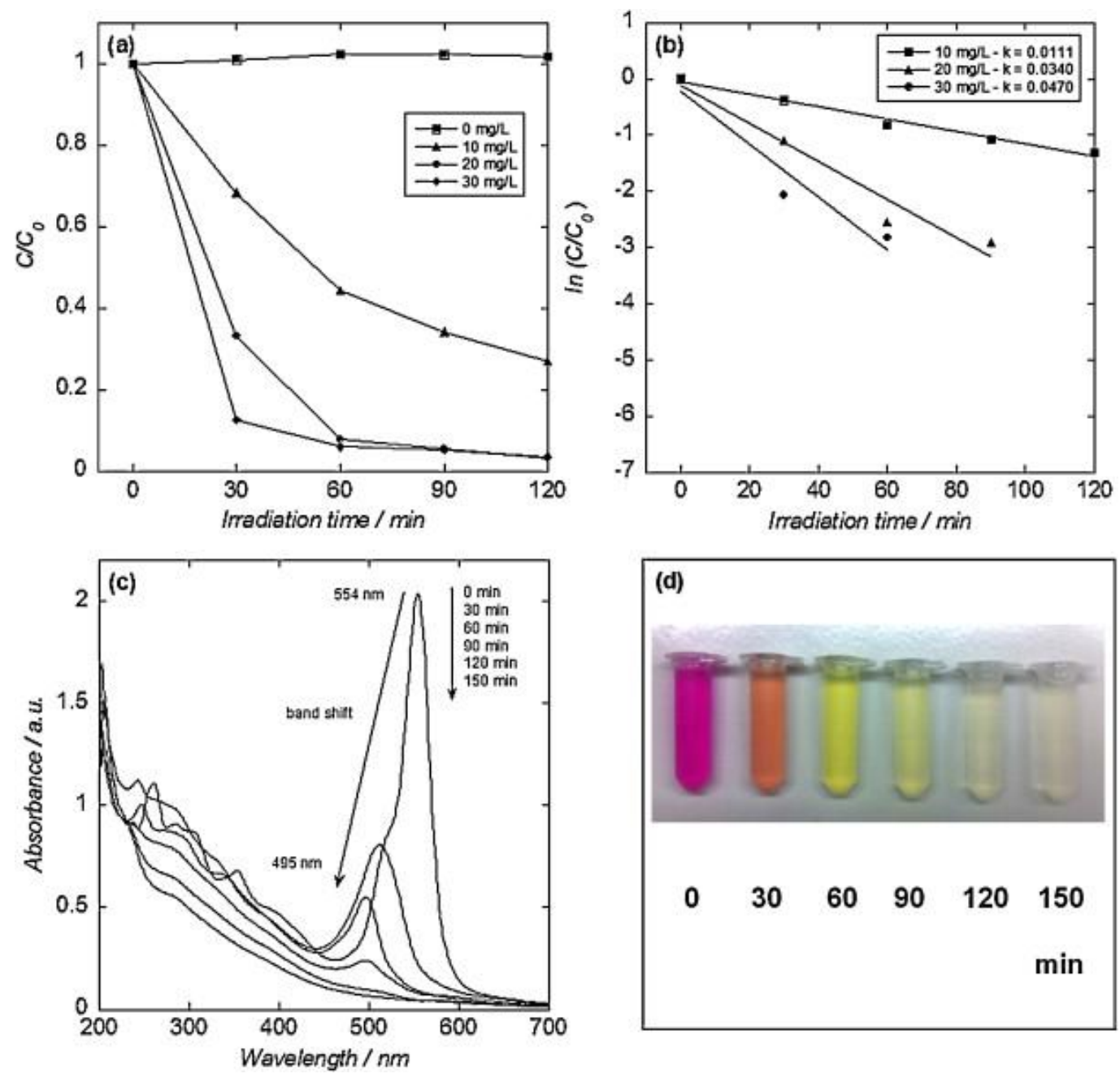

Fig. 13 (a) Temporal course of photocatalytic degradation of $\mathrm{RhB}$ at different concentrations of $\mathrm{Na}_{2}\left[\mathrm{Mo}_{6} \mathrm{Br}_{8}\left(\mathrm{~N}_{3}\right)_{6}\right]$ cluster precursor under direct solar light; (b) first-order re-plot in $\ln (\mathrm{C} / \mathrm{C} 0)$ versus irradiation time; (c) UV-vis absorption spectra of rhodamine $\mathrm{B}$ before and after irradiation in the presence of $\mathrm{Na}_{2}\left[\mathrm{Mo}_{6} \mathrm{Br}_{8}\left(\mathrm{~N}_{3}\right)_{6}\right]$ cluster precursor at $30 \mathrm{mg} \mathrm{L}^{-1}$ as a function of irradiation time under direct solar light; (d) photos of RhB solutions before (0) and after solar irradiation for 30, 60, 90, 120, and 150 min in the presence of $\mathrm{Na}_{2}\left[\mathrm{Mo}_{6} \mathrm{Br}_{8}\left(\mathrm{~N}_{3}\right)_{6}\right]$ cluster precursor at $30 \mathrm{mg} \mathrm{L}{ }^{-1}$; the initial concentration of $\mathrm{RhB}$ is $10 \mathrm{mg} \mathrm{L}^{-1}$. (For interpretation of the references to color in this figure legend, the reader is referred to the web version of the article.). Reprinted with permission from [119]. Copyright $\{2012\}$ Elsevier

In the frame of green chemistry applications, the cluster units should have to be supported on a substrate. Despite we developed several strategies to immobilize $\mathbf{M}_{6}$ clusters onto silicon surface via organic linkers [120-121], we chose another strategy consisting of immobilization of $\mathrm{Mo}_{6}$ clusters onto graphene oxide (GO) in the presence of gold salt. Indeed, the technique relies on the UV irradiation of GO in the presence of $\mathrm{Na}_{2}\left[\mathrm{Mo}_{6} \mathrm{Br}_{8}\left(\mathrm{~N}_{3}\right)_{6}\right]$ and $\mathrm{HAuCl}_{4} \cdot 3 \mathrm{H}_{2} \mathrm{O}$. This is a versatile one pot synthetic route for the preparation of AuNPs@GO-Mo nanocomposite [122]. The resulting material showed excellent photocatalytic performance for the degradation of rhodamine B under visible light irradiation. Indeed, the tri-component 
material is built up on $\mathrm{GO}$ as supporting material, $\mathrm{Au}$ nanoparticles and $\mathrm{Mo}_{6}$ clusters. $\mathrm{Mo}_{6}$ clusters are the photoactive species, Au NPs may participate in the photocatalytic process by enhancing charge separation and because of the low photocatalytic activity of GO alone, it is believed that its role in the photocatalytic process is to favor $\mathrm{RhB}$ adsorption on the nanohybrid surface via $\pi-\pi$ stacking.

Last but not least, $\left[\mathrm{Mo}_{6} \mathrm{Br}_{8}^{\mathrm{i}} \mathrm{Br}_{6}^{\mathrm{a}}{ }_{6}\right]^{2-}$ octahedral molybdenum cluster units were found to be efficient visible light homogeneous photocatalysts for the reduction of carbon dioxide $\left(\mathrm{CO}_{2}\right)$ to methanol [123]. Photoreduction was carried out by using 20 watt white cold LED flood light in dimethyl formamide/water or acetonitrile/water solutions containing triethylamine as a reductive quencher (Scheme 2). Among the two cluster-based compounds, $\mathrm{Cs}_{2}\left[\mathrm{Mo}_{6} \mathrm{Br}_{14}\right]$ exhibited higher photocatalytic efficiency and afforded higher yield of methanol than (n$\left.\mathrm{Bu}_{4} \mathrm{~N}\right)_{2}\left[\mathrm{Mo}_{6} \mathrm{Br}_{14}\right]$. After $24 \mathrm{~h}$ illumination, the yield of methanol was 6679.45 and 5550.53 mmol $\mathrm{g}^{-1}$ cat. using $\mathrm{Cs}_{2}\left[\mathrm{Mo}_{6} \mathrm{Br}_{14}\right]$ and $\left(\mathrm{n}-\mathrm{Bu}_{4} \mathrm{~N}\right)_{2}\left[\mathrm{Mo}_{6} \mathrm{Br}_{14}\right]$ cluster compounds as photocatalysts, respectively.

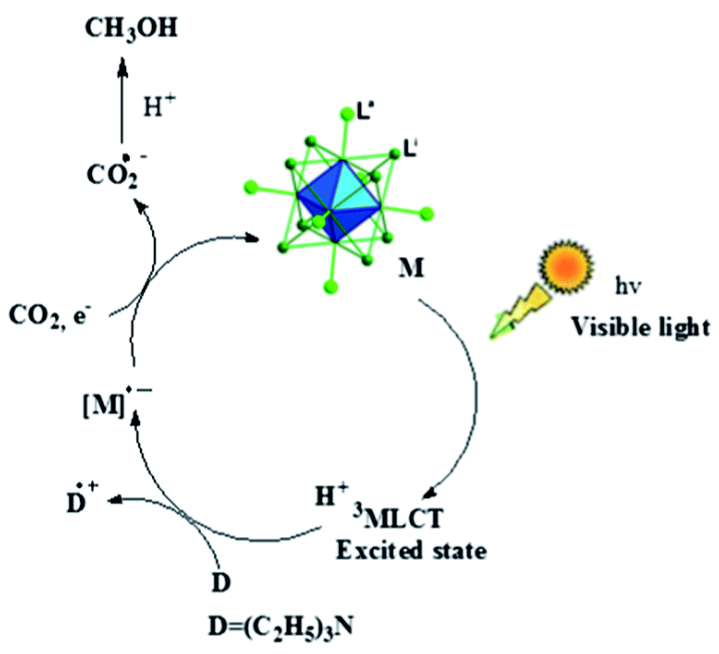

Scheme 2 Possible mechanistic pathway for $\mathrm{CO}_{2}$ photoreduction using $\mathrm{Mo}_{6}$ clusters [123] - Reproduced by permission of The Royal Society of Chemistry

Beyond these photocatalytic properties, cluster-based materials exhibit very interesting catalytic properties that have been widely studied by the group of Kamigushi and Chihara. As non-exhaustive results, let's cite the dehydration of alcohol to olefin and ether [124], the isomerization of alkynes to conjugated dienes under nitrogen and hydrogenation to alkenes under hydrogen [125] or gas-phase S-alkylation of benzenethiol with aliphatic alcohols, ethers, esters, alkyl halides and olefins [126]. 


\section{Conclusion}

Based on our recent results and keeping in mind the general term of nanoarchitectonics referring to a technology system for arranging nanoscale structural units in a required architecture, we have demonstrated in this microreview that metal atom clusters are relevant building blocks for nanoarchitectonics. Indeed, metal atom cluster units are versatile building blocks that exhibit a well-defined organization of twenty atoms leading to a monodispersed size. Beyond carrying specific luminescence, sensitization, catalytic and photo-catalytic properties, they were involved in the structuration by self-assembling of organic cationic frameworks in charge transfer salts thanks to their ability to form hydrogen bonding. Concerning the latter point, fluorinated metal atom clusters with low molecular weight should be relevant nanoscale structural units to improve the hydrogen storage capacity of MOF. After dissolution of solid state precursors, the clusters functionalization is carried out either by pairing anionic cluster units with functional cations or by exchange of -at least one of the sixapical halogens by functional organic ligands. This functionalization imporves their incorporation either in inorganic silica matrix or in organic copolymers and enables selfassembling in clustomesogens. The nanoarchitectonics of metal atom clusters building blocks is now a field of research with wide range of potential applications like for instance in green chemistry, biotechnologies, imaging and lighting technologies.

\section{Acknowledgements}

We are grateful to T. Aubert, C. Neaime, N. Nerambourg, J.F. Dechezelles, M. A. Shestopalov, A. Y. Ledneva, O.A. Efremova and F. Dorson who made a part of their PhD or post-doc work on this research topic. The authors thank Dr. P. Gredin from University of Paris 6-France, Dr. G. Patriarche at Laboratoire de Photonique et de Nanostructures (LPNCNRS), Prof. G. Férey and Dr C. Serre from Institut Lavoisier Versailles, Prof. S. L. Jain from Chemical Sciences Division, CSIR-Indian Institute of Petroleum Mohkampur, Prof. K. Kimoto and Prof. Y. Bando from NIMS-Japan, Prof. G. Saito and Dr Y. Yoshida from Faculty of Agriculture, Meijo University, Shiogamaguchi for very fruitful collaborations. These works have been supported by YCIS-NIMS, UR1, CNRS, Region Bretagne and ANR (CLUSTOP-11-BS08-013-01; CLUSTOMESOGEN-13-BS07-0003-01). 


\section{References}

1. P. S. Weiss, ACS Nano 1, 379 (2007)

2. K. Ariga, Y. Yamauchi, G. Rydzek, Q. Ji, Y. Yonamine, K. C.-W. Wu, J.P. Hill., Chem. Lett. 43(1), 36 (2014)

3. K. Ariga, A. Vinu, Y. Yamauchi, Q. Ji, J.P. Hill, Bull. Chem. Soc. Jpn. 85(1), 132 (2012)

4. R. Liu, J. Duaya, S. Bok Lee, Chem. Commun. 47, 1384 (2011)

5. R.W. Murray, Chem. Rev. 108(7), 2705 (2008)

6. H.X. Xu, K.S. Suslick, Adv. Mater. 22, 3209 (2010)

7. M. Turner, V.B. Golovko, O.P. Vaughan, P. Abdulkin, A. Berenguer-Murcia, M.S. Tikhov, B.F. Johnson, R.M. Lambert, Nature 454(7207), 981 (2008)

8. F.A. Cotton, Inorg. Chem. 3, 1217 (1964)

9. Y. Lu, W. Chen, Chem. Soc. Rev. 41, 3594 (2012)

10. R.C. Jin, Nanoscale 2, 343 (2010)

11. L. Shang, S. Dong, G.U. Nienhaus, Nano Today 6, 401 (2011)

12. A. Perrin, C. Perrin, C. R. Chim. 15, 815 (2012)

13. H.-T. Sun, Y. Sakka, Sci. Technol. Adv. Mater. 15, 014205 (2014)

14. S. Cordier, Y. Molard, K.A. Brylev, Y.V. Mironov, F. Grasset, B. Fabre, N.G. Naumov, J. Clust. Sci. (2014) doi 10.1007/s10876-014-0734-0

15. A.W. Maverick, H.B. Harry, J. Am. Chem. Soc. 103, 1298 (1981)

16. J.G. Converse, R.E. McCarley, Inorg. Chem. 9, 1361 (1970)

17. B. Peric, S. Cordier, J. Cuny, R. Gautier, T. Guizouarn, P. Planinic, Chem. Eur. J. 17, $6263(2011)$

18. S. Cordier, F. Dorson, F. Grasset, Y. Molard, B. Fabre, H. Haneda, T. Sasaki, M. Mortier, S. Ababou-Girard, C. Perrin, J. Clust. Sci. 20, 9 (2009)

19. D. Mery, C. Ornelas, M.C. Daniel, J. Ruiz, J. Rodrigues, D. Astruc, S. Cordier, K. Kirakci, C. Perrin, C. R. Chim. 8, 1789 (2005) 
20. S. Cordier, K. Kirakci, D. Meŕy, C. Perrin, D. Astruc, Inorg. Chem. Acta 359, 1705 (2006)

21. S. Cordier, N.G. Naumov, D. Salloum, F. Paul, C. Perrin, Inorg. Chem. 43, 219 (2004)

22. K. Kirakci, S. Cordier, O. Hernandez, T. Roisnel, F. Paul, C. Perrin, J. Solid State Chem. 178, $3117(2005)$

23. A. Demont, C. Prestipino, O. Hernandez, E. Elkaim, S. Paofai, N.G. Naumov, B. Fontaine, R. Gautier, S. Cordier, Chem.-Eur. J. 19, 12711 (2013)

24. N.G. Naumov, S. Cordier, C. Perrin, Solid State Sci. 5, 1359 (2003)

25. N.G. Naumov, S. Cordier, C. Perrin, Solid State Sci. 7, 1517 (2005)

26. M.A. Shestopalov, A. Ledneva, S. Cordier, O. Hernandez, M. Potel, T. Roisnel, N.G. Naumov, C. Perrin, Angew. Chem. Int. Ed. 50, 7300 (2011)

27. L. Cario, C. Vaju, B. Corraze, V. Guiot, E. Janod, Adv. Mater. 22, 5193 (2010)

28. S. Cordier, B. Fabre, Y. Molard, A.-B. Fadjie-Djomkam, N. Tournerie, A. Ledneva, N. G. Naumov, A. Moreac, P. Turban, S. Tricot, S. Ababou-Girard, C. Godet, J. Phys. Chem. C 114, $18622(2010)$

29. B. Fontaine, S. Cordier, R. Gautier, F. Gulo, J.-F. Halet, B. Peric, C. Perrin, New J. Chem. 35, 2245 (2011).

30. A. Simon, G. Schmidt, Ed., Verlag Chemie: Weinheim, 373 (1994)

31. C. Perrin, J. Alloys Comp. 263 (1997)

32. N. Barrier, B. Fontaine, S. Pierrefixe, R. Gautier, P. Gougeon, Inorg. Chem. 48, 3848 (2009)

33. M. Potel, R. Chevrel, M. Sergent, J. Solid State Chem. 35, 286 (1980)

34. P. Murugan, V. Kumar, Y. Kawazoe, N. Otta, Appl. Phys. Lett. 92, 203112 (2008)

35. R. Llusar, C. Vicent., Coord. Chem. Rev. 254, 1534 (2010)

36. J. Kibsgaard, T. F. Jaramillo, F. Besenbacher, Nature Chem. 6, 248 (2014)

37. R. Chevrel, M. Sergent, J. Prigent, J. Solid State Chem. 3, 515 (1971)

38. C. Perrin, M. Sergent, J. Chem. Res. (S) 38 (1983) 
39. M. Remska, A. Mrzel, M. Virsek, A. Jesih, Adv. Mater. 19, 4276 (2007)

40. V. Domenici, M. Conradi, M. Remskar, M. Virsek, B. Zupancic, A. Mrzel, M. Chambers, B. Zalar, J. Mater. Sci. 46, 3639 (2011)

41. D. Vrbani, M. Remskar, A. Jesih, A. Mrzel, P. Umek, M. Ponikvar, B. Jancar, A. Meden, B. Novosel, S. Pejovnik, P. Venturini, J.C. Coleman, D. Mihailovic, Nanotechnology 15, 635 (2004)

42. D. Mihailovic, Prog. Mater. Sci. 54, 309 (2009)

43. L. Joly-Pottuz, F. Dassenoy, J. Martin, D. Vrbanic, A. Mrzel, D. Mihailovic, W. Vogel, G. Montagnac, Tribol. Lett. 18, 385 (2005)

44. J.J. Doyle, V. Nicolosi, S.M. O’Flaherty, D. Vengust, A. Drury, D. Mihailovic, J.N. Coleman, W. Blau, J. Chem. Phys. Lett. 435, 109 (2007)

45. D. Vengust, F. Pfuner, L. Degiorgi, I. Vilfan, V. Nicolosi, J.N. Coleman, D. Mihailovic, Phys. Rev. B: Condens. Matter Mater. Phys. 76, 075106 (2007)

46. F. Dassenoy, L. Joly-Pottuz, J. Martin, D. Vrbanic, A. Mrzel, D. Mihailovic, W. Vogel, G. Montagnac, J. Eur. Ceram. Soc. 27, 915 (2007)

47. V. Nicolosi, D. Vrbanic, A. Mrzel, J. McCauley, S. O’Flaherty, C. McGuinness, G. Compagnini, D. Mihailovic, W.J. Blau, J.N. Coleman, J. Phys. Chem. B 109, 7124 (2005)

48. V. Nicolosi, D. Vrbanic, A. Mrzel, J. McCauley, S. O’Flaherty, D. Mihailovic, W.J. Blau, J.N Coleman, Chem. Phys. Lett. 401, 13 (2005)

49. D.N. McCarthy, V. Nicolosi, D. Vengust, D. Mihailovic, G. Compagnini, W.J. Blau, J.N. Coleman, J. Appl. Phys. 101, 014317 (2007)

50. D.G. Nocera, H.B. Gray, J. Am. Chem. Soc. 106, 824 (1984)

51. C. Feldmann, T. Juestel, C. R. Ronda, P. J. Schmidt, Adv. Funct. Mater. 13, 511 (2003)

52. K. Binnemans, Chem. Rev. 109, 4283 (2009)

53. J.-C.G. Bunzli, S.V. Eliseeva, J. Rare Earths 28, 824 (2010)

54. C. Zhang, J. Lin, Chem. Soc. Rev. 41, 7938 (2012)

55. E. Holder, N. Tessler, A.L. Rogach, J. Mater. Chem. 18, 1064 (2008) 
56. B. Moraru, N. Huesing, G. Kickelbick, U. Schubert, P. Fratzl, H. Peterlik, Chem. Mater. 14, 2732 (2002)

57. S. Gross, V. Di Noto, U. Schubert, J. Non-Cryst. Solids 322, 154 (2003)

58. J.H. Golden, H.B. Deng, F.J. Disalvo, J.M.J. Frechet, P.M. Thompson, Science 268, 1463 (1995)

59. O.A. Adamenko, G.V. Lukova, N.D. Golubeva, V.A. Smirnov, G.N. Boiko, A.D. Pomogailo, I.E. Uflyand, Dokl. Phys. Chem. 381, 275 (2001)

60. O.A. Adamenko, G.V. Loukova, V.A. Smirnov, Russ. Chem. Bull. 51, 994 (2002)

61 N.D. Golubeva, O.A. Adamenko, G.N. Boiko, L.A. Petrova, Y.A. Ol'khov, A.D. Pomogailo, Inorg. Mater. 40, 306 (2004)

62. L. M. Robinson, D.F. Shriver, J. Coord. Chem. 37, 119 (1996)

63. J.A. Jackson, M.D. Newsham, C. Worsham, D.G. Nocera, Chem. Mater. 8, 558 (1996)

64. R.N. Ghosh, G.L. Baker, C. Ruud, D.G. Nocera, Appl. Phys. Lett. 75, 2885 (1999)

65. Y. Molard, C. Labbe, J. Cardin, S. Cordier, Adv. Funct. Mater. 23, 4821 (2013)

66. T. Aubert, N. Nerambourg, N. Saito, H. Haneda, N. Ohashi, M. Mortier, S. Cordier, F. Grasset, Part. Part. Syst. Charact. 30, 90 (2013)

67. M. Amela-Cortes, A. Garreau, S. Cordier, E. Faulques, J.-L. Duvail, Y. Molard, J. Mater. Chem. C 2, 1545 (2014)

68. J. Michas, C.M. Paleos, P. Dais, Liquid Cryst. 5, 1737 (1989)

69. J. Eastoe, M. Summers, R.K. Heenan, Chem. Mater. 12, 3533 (2000)

70. H.K. Bisoyi, S. Kumar, Chem. Soc. Rev. 40, 306 (2011)

71. C. Tschierske, Angew. Chem. Int. Ed. 52, 8828 (2013)

72. D.W. Bruce, Adv. Mater. 6, 699 (1994)

73. R.W. Date, E.F. Iglesias, K.E. Rowe, J.M. Elliott, D.W. Bruce, Dalton Trans. 1914 (2003). 
74. M. Amela-Cortes, F. Dorson, M. Prévôt, A. Ghoufi, B. Fontaine, F. Goujon, R. Gautier, V. Cîrcu, C. Mériadec, F. Artzner, H. Folliot, S. Cordier, Y. Molard, Chem. Eur. J. 20, 8561 (2014)

75. A.S. Mocanu, M. Amela-Cortes, Y. Molard, V. Circu, S. Cordier, Chem. Commun. 47, $2056(2011)$

76. Y. Molard, F. Dorson, V. Circu, T. Roisnel, F. Artzner, S. Cordier, Angew. Chem. Int. Ed. 49, $3351(2010)$

77. I.M. Saez, J.W. Goodby, Struct. Bond. 128, 1 (2008)

78. W.A. MacDonald, J. Mater. Chem. 14, 4 (2004)

79. P. Massé, S. Reculusa, K. Clays, S. Ravaine, Chem. Phys. Lett., 422, 251 (2006)

80. P. Massé, G. Pouclet, S. Ravaine, Adv. Mater. 20, 584 (2008)

81. P. Massé, R. A. L. Vallée, J.-F. Dechézelles, J. Rosselgong, E. Cloutet, H. Cramail, X.S. Zhao, S. Ravaine, J. Phys. Chem. C 113, 14487 (2009)

82. J.-F. Dechézelles, T. Aubert, F. Grasset, S. Cordier, C. Barthou, C. Schwob, A. Maitre, R. A. L. Vallée, H. Cramail, S. Ravaine, Phys. Chem. Chem. Phys. 12, 11993 (2010)

83. K. Tanaka, Y. Chujo, Adv. Powder Technol. 25, 101 (2014)

84. M. Naito, T. Ishii, A. Matsumoto, K. Miyata, Y. Miyahara, K. Kataoka, Angew. Chem. Int. Ed. 51, 10751 (2012)

85. J.L. Vivero-Escoto, R.C. Huxford-Phillips, W. Lin, Chem. Soc. Rev. 41, 2673 (2012)

86. E. Duguet, S. Vasseur, S. Mornet, G. Goglio, A. Demourgues, J. Portier, F. Grasset, P. Veverka, E. Pollert, Bull. Mater. Sci. 29(6), 581 (2006)

87. F. Grasset, F. Dorson, S. Cordier, Y. Molard, C. Perrin, A. M. Marie, T. Sasaki, H. Haneda, Y. Bando, M. Mortier, Adv. Mater. 20, 143 (2008)

88. T. Aubert, A.Y. Ledneva, F. Grasset, K. Kimoto, N.G. Naumov, Y. Molard, N. Saito, H. Haneda, S. Cordier, Langmuir 26, 18512 (2010)

89. F. Grasset, F. Dorson, Y. Molard, S. Cordier, V. Demange, C. Perrin, V. Marchi- Artzner, H. Haneda, Chem. Commun. 4729 (2008) 
90. C. Neaime, N. Nerambourg, T. Aubert, F. Grasset, S. Cordier, P. Gredin, M. Mortier, Key Eng. Mater. 617, 174 (2014)

91. T. Aubert, F. Cabello Hurtado, M.A. Esnault, C. Neaime, D. Lebret-Chauvel, S. Jeanne, P. Pellen, C. Roiland, L. Le Polles, N. Saito, K. Kimoto, H. Haneda, N. Ohashi, F. Grasset, S. Cordier, J. Phys. Chem. C 117, 20154 (2013)

92. N. Nerambourg, T. Aubert, C. Neaime, S. Cordier, M. Mortier, G. Patriarche, F. Grasset, J. Colloid Interface Sci. 424, 132 (2014)

93. A.W. Maverick, J.S. Najdzionek, D. MacKenzie, D.G. Nocera, H.B. Gray, J. Am. Chem. Soc. 105, $1878(1983)$

94. C.H. Contag, B.D. Ross, J. Magn. Reson. Imaging 16, 378 (2002)

95. L. Gao, M.A. Peay, T.G. Gray, Chem. Mater. 22, 6240 (2010)

96. Z. Guo, S. Park, J. Yoon, I. Shin, Chem. Soc. Rev. 43, 16 (2014)

97. Z. Li, Q. Sun, Y. Zhu, B. Tan, Z. Ping Xu, S. Xue Dou, J. Mater. Chem. B 2, 2793 (2014)

98. E. Hemmer, N. Venkatachalam, H. Hyodo, A. Hattori, Y. Ebina, H. Kishimoto, K. Soga, Nanoscale 5, 11339 (2013)

99. V. Roullier, F. Grasset, F. Boulmedais, F. Artzner, O. Cador, V. Marchi-Artzner, Chem. Mater. 20, 6657 (2008)

100. S. Nagarajan, Z. Li, V. Marchi-Artzner, F. Grasset, Y. Zhang, Med. Biol. Eng. Comput. 48, 1033 (2010)

101. F. Grasset, N. Labhsetwar, D. Li, D. C. Park, N. Saito, H. Haneda, O. Cador, T. Roisnel, S. Mornet, E. Duguet, J. Portier, J. Etourneau, Langmuir 18, 8209 (2002)

102. F. Grasset, R. Marchand, A. M. Marie, D. Fauchadour, F. Fajardie, J. Colloid Interface Sci. 299, 726 (2006)

103. M.A. Lopez-Quintela, Curr. Opin. Colloid Interface Sci. 8, 137 (2003)

104. T. Aubert, F. Grasset, S. Mornet, E. Duguet, O. Cador, S. Cordier, Y. Molard, V. Demange, M. Mortier, H. Haneda, J. Colloid Interface Sci. 341, 301 (2010)

105. J. Wang, Z. Hussain Shah, S. Zhang, R. Lu, Nanoscale, 6, 4418 (2014) 
106. K. Kirakci, H. Hosoda, S. Cordier, C. Perrin, G. Saito, J. Solid State Chem. 179, 3628 (2006)

107. G. Saito, H. Hosoda, Y. Yoshida, J. Hagiwara, K. Nishimura, H. Yamochi, A. Otsuka, T. Hiramatsu, Y. Shimazaki, K. Kirakci, S. Cordier, C. Perrin, J. Mater. Chem. 22, 19774 (2012) 108. Y. Yoshida, M. Maesato, Y. Kumagai, M. Mizuno, K. Isomura, H. Kishida, M. Izumi, Y. Kubozono, A. Otsuka, H. Yamochi, G. Saito, K. Kirakci, S. Cordier, C. Perrin, Eur. J. Inorg. Chem. DOI: 10.1002/ejic.201400119 (2014)

109. P.J. Krusic, E. Wasserman, J. Am. Chem. Soc. 113, 2322 (1991)

110. D. Dybtsev, C. Serre, B. Schmitz, B. Panella, M. Hirscher, M. Latroche, P. L. Llewellyn, S. Cordier, Y. Molard, M. Haouas, F. Taulelle, G. Ferey, Langmuir 26, 11283 (2010)

111. G. Ferey, C. Serre, F. Millange, C. Mellot-Draznieks, E.S. Surbl, J. Dutour, I. Margiolaki, Angew. Chem., Int. Ed. 43, 6296 (2004)

112. G. Ferey, C. Mellot-Draznieks, C. Serre, F. Millange, J. Dutour, S. Surble, I. Margiolaki, Science 309, 2040 (2005)

113. G.J. Wessel, D.J. W. Ijdo, Acta Crystallogr. 10, 466 (1957)

114. R. Stranger, A. Turner, C. D. Delfs, Inorganic Chemistry 40, 17 (2001)

115. K. W. Krämer, R. Schenker, J. Hauser, H. Weihe, H. U. Güdel, H.-B. Bürgi, Z. anorg. allg. Chem. 627, 2511 (2001)

116. G. Prabusankar, Y. Molard, S. Cordier, S. Golhen, Y. Le Gal, C. Perrin, L. Ouahab, S. Kahlal, J.-F. Halet, Eur. J. Inorg. Chem. 2153 (2009)

117. T. Yoshimura, S. Ishizaka, T. Kashiwa, A. Ito, E. Sakuda, A. Shinohara, N. Kitamura, Inorg. Chem. 50, 9918 (2011)

118. G. Pilet, S. Cordier, S. Golhen, C. Perrin, L. Ouahab, A. Perrin, Solid State Sci. 5, 1263 (2003)

119. A. Barras, S. Cordier, R. Boukherroub, Appl. Catal. B: Environ. 123, 1 (2012)

120. B. Fabre, S. Cordier, Y. Molard, C. Perrin, S. Ababou-Girard, C. Godet, J. Phys. Chem. C 113, 17437 (2009). 
121. S. Cordier, B. Fabre, Y. Molard, A. B. Fadjie-Djomkam, N. Tournerie, A. Ledneva, N.G. Naumov, A. Moreac, P. Turban, S. Tricot, S. Ababou-Girard, C. Godet, J. Phys. Chem. C 114, $18622(2010)$

122. A. Barras, M. R. Das, R. R. Devarapalli, M. V. Shelke, S. Cordier, S. Szunerits, R. Boukherroub, Appl. Catal. B: Environ. 130, 270 (2013)

123. P. Kumar, S. Kumar, S. Cordier, S. Paofai, R. Boukherroub, S. L. Jain, RSC Adv. 4, $10420(2014)$

124. S. Kamiguchi and T. Chihara, Catal. Lett. 85, 97 (2003)

125 S. Kamiguchi, S. Takaku, M. Kodomari, T. Chihara, J. Mol. Catal. A: Chemical 260, 43 (2006)

126. S. Nagashima, K. Kudo, H. Yamazaki, S. Kamiguchi, T. Chihara, Appl. Catal. A: General 450, 50 (2013) 